\title{
ANGELUS NOVUS. PAUL KLEEY WALTER BENJAMIN. DEL ARTE A LA FILOSOFÍA ${ }^{1}$
}

\author{
ANGELUS NOVUS. PAUL KLEE Y WALTER BENJAMIN. \\ FROM ART TO PHILOSOPHY \\ ANGELUS NOVUS, PAUL KLEE, WALTER BENJAMIN. \\ DA ARTE À FILOSOFIA
}

Por:

\author{
Juliane Bambula Díaz ${ }^{2}$ \\ Profesora \\ Universidad del Valle \\ julianebambuladiaz@yahoo.com
}

Resumen: Este artículo acerca de la relación entre arte y filosofía se ocupa de formas: formas visuales, formas de pensar, configuraciones culturales y formas de organización de ideas y de sus conexiones. El propósito es mostrar cómo el arte de vanguardia es capaz de anticipar e inducir cambios epistemológicos que luego se incorporan en la teoría del conocimiento y se convierten en parte de nuevos paradigmas, diferentes al pensamiento hegemónico occidental. Punto de partida y ejemplo central de esta reflexión es el conocido caso de la pintura Angelus Novus de Paul Klee que sirvió de inspiración para nuevas formas de pensamiento desarrollados por Walter Benjamin, que actualmente revisten gran interés en los debates teóricos a nivel internacional.

Palabras claves: Pintura, filosofía, epistemología, rizoma, locus enuntiationis, vanguardias artísticas, historia.

Abstract: This article about the relationship between art and philosophy, deals with forms: visual forms, forms of thinking, forms of cultural configuration and forms of organization of ideas and their connections. The purpose is to show how avant-garde art is able to anticipate and induce epistemological changes that are later incorporated into the theory of knowledge and become part of new paradigms, different to Western hegemonic thinking. Starting point and central example of this reflection is the wellknown case of Paul Klee's painting Angelus Novus that served as inspiration for new ways of thinking developed by Walter Benjamin, currently of great interest in theoretical debates at international level.

Keywords: Painting, philosophy, epistemology, rhizome, locus enuntiationis, avantgarde art, history. 
Resumo: Este artigo sobre a relação entre arte e filosofia ocupa-se das formas: formas visuais, formas de pensamento, formas de configurações culturais e formas de organização de ideias e as suas conexões. O propósito é mostrar como a arte de vanguarda é capaz de antecipar e induzir mudanças epistemológicas que depois incorporam-se na teoria do conhecimento e transformam-se em parte dos novos paradigmas, diferentes ao pensamento hegemônico ocidental. O ponto de partida e o exemplo central desta reflexão é o conhecido caso da pintura Angelus Novus de Paul Klee, que inspirou as novas formas de pensamento desenvolvido por Walter Benjamin, as quais têm grande interesse nos debates teóricos internacionalmente.

Palavras-chave: Pintura, filosofia, epistemologia, rizoma, locus enuntiationis, vanguardas artísticas, história.

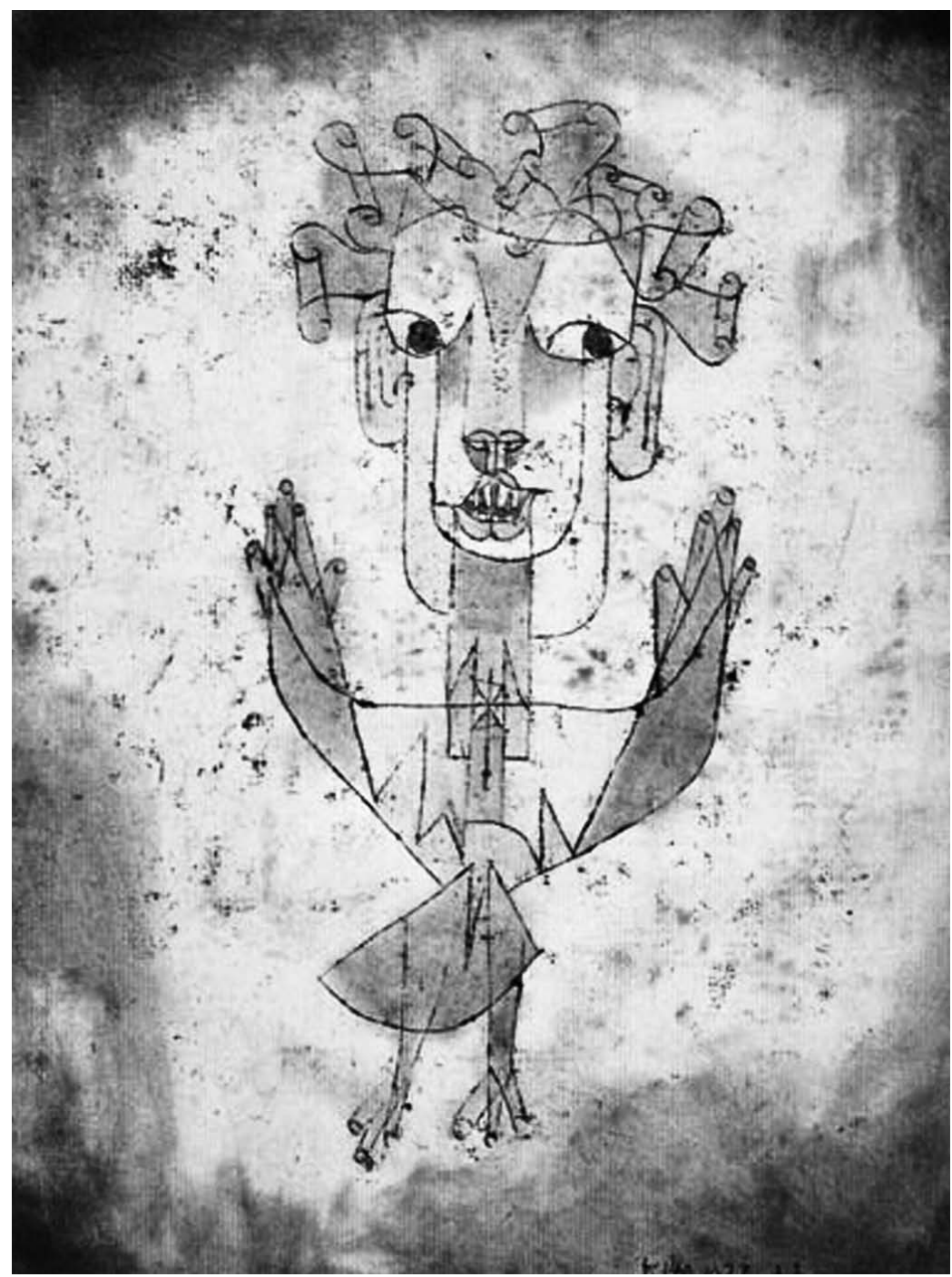

1. Paul Klee, Angelus Novus, 1920, dibujo a tinta china, tiza y acuarela sobre papel, Museo de Israel, Jerusalén 
Este texto trata de formas: formas visuales, formas de pensar y formas de organizar ideas. En ese último aspecto se explicita un problema epistemológico que también está presente, pero de manera latente, en los primeros dos aspectos. Para ello hago uso del ejemplo de dos grandes figuras del siglo XX, el pintor Paul Klee y el filósofo y teórico de la cultura Walter Benjamin.

El texto se divide en cuatro partes. Inicia con un preámbulo, en el que se presentan los dos protagonistas, Paul Klee y Walter Benjamin, y en el que se formula una tesis. En las dos partes principales, llamadas Los pájaros en picada. Acerca del locus enuntiationis y La alfombra del recuerdo Acerca del pensamiento descentralizado se desarrolla la tesis mediante dos ejemplos. Al final, en cuarto lugar, hay una pequeña Posdata.

\section{Preámbulo}

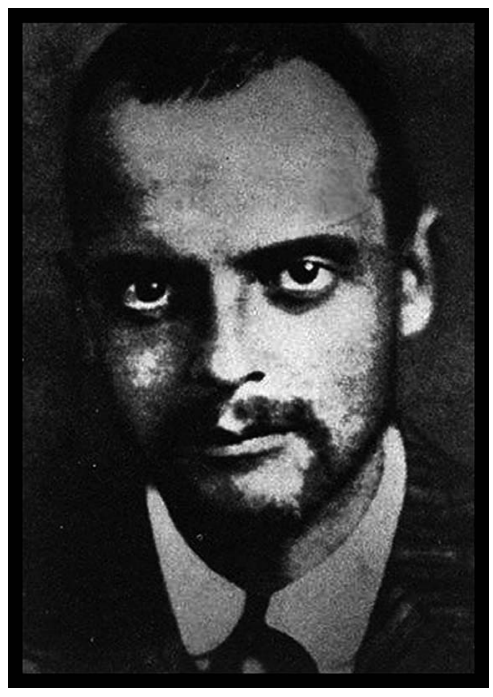

2.Paul Klee, pintor, 1879-1940

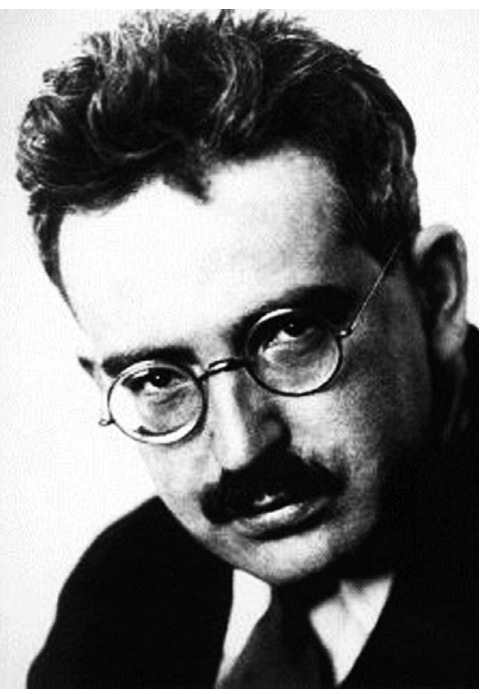

3.Walter Benjamin, filósofo, 1892-1940

Benjamin y Klee son dos destacados intelectuales del siglo XX que nunca se conocieron personalmente y que tuvieron de cierta manera destinos similares, aunque Benjamin naciera trece años más tarde que Klee. Pero, más allá de ese paralelismo, existe un vínculo intelectual profundo e indeleble entre los dos que se condensa en forma anecdótica y simbólica en la realidad física de un pequeño cuadro de Klee, con el título de Angelus Novus, que fue en su momento adquirido por Walter Benjamin y que es el vestigio de una comunión de ideas entre ambos y del nacimiento de un nuevo enfoque epistemológico en la comprensión de los procesos sociales y culturales que hoy, a finales del siglo XX y comienzo del siglo XXI, adquieren cada vez más fuerza como parte de los nuevos paradigmas de conocimeinto que se van imponiendo. 


\section{Paul Klee}

Paul Klee era un pintor suizo-alemán, que hacía parte de las vanguardias artísticas de la primera mitad del siglo XX. Junto con Kandinsky, fue uno de los más destacados integrantes del grupo expresionista El Jinete Azul - Der blaue Reiter, que fue activo a partir de 1911 en el sur de Alemania, en Múnich y sus alrededores y tiene amplia repercusión hasta hoy a nivel internacional. Durante los años veinte Klee trabajó, junto con Kandinsky y otras figuras sobresalientes del arte vanguardista de aquella época, como maestro en la Bauhaus.

La Bauhaus era una escuela de arte y diseño que funcionó entre 1919 y 1933 en Alemania y cuyos avances cambiaron radicalmente las formas del entorno arquitectónico y de los objetos de uso cotidiano en el mundo. La Bauhaus marcó pautas que nos acompañan en todo el mundo hasta hoy - en cuanto a las formas de los objetos que nos rodean y con los cuales interactuamos a diario. Allí Klee jugó un papel importante.

La Bauhaus fue cerrada cuando en 1933 los nazis llegaron al poder en Alemania. Ellos perseguían no solo los opositores políticos y las personas de supuesta "raza no aria", sino también a los artistas de vanguardia. También las obras de Klee fueron colocadas en el índice como "arte degenerado" y su persona fue objeto de estas persecuciones. Emigró a Suiza para resguardar su vida. Allí se deprimió al grado de enfermarse gravemente. Interrumpió durante unos años su actividad creativa, pero la retomó a finales de los años treinta entrando en una última fase de gran productividad artística. Murió en 1940 de esclerodermia.



4. La última foto de Paul Klee, tomada el día 20 de febrero 1940
Aunque Klee había hecho parte del grupo expresionista, su obra no es típicamente expresionista, sino más bien sui generis, muy personal y singular. Se podría decir que se ubica en medio del expresionismo, del surrealismo y un anticipado arte conceptual. Se inspira en la síntesis espontánea y encantadora del dibujo infantil y da rienda suelta a ocurrencias visual-conceptuales que brotan de las complejas concatenaciones mentales generadas por la vida cotidiana, siendo en ese sentido un verdadero precursor de tendencias artísticas que adquieren importancia a finales del siglo XX y comienzos del siglo XXI.

Antes de su exilio Klee fue celebrado por la crítica en diferentes países europeos y considerado como el mejor pintor moderno en Alemania, opinión que él mismo, con la modestia que le caracterizaba, no compartía. 


\section{Walter Benjamin}

Walter Benjamin, trece años menor que Klee, fue un filósofo alemán, teórico de la cultura, ensayista, crítico literario y traductor de obras de literatura. Era hijo de una familia acomodada de ascendencia judía de Berlín. Había cultivado desde su época estudiantil el interés por la filosofía, la literatura, el lenguaje, la historia, el arte y la tecnología como fenómeno cultural. En 1915, a través de su amistad con Gershom Scholem, un estudioso de la mística talmúdica, entró en contacto con el judaísmo. Apartir de 1924 se acercó al marxismo.

Conoció a la revolucionaria bolchevique lituana Asja Lacis, una actriz, directora de teatro y pedagoga social que era el eslabón de contacto entre el teatro vanguardista ruso de Meyerhold y Mayakowsky y el teatro vanguardista alemán de Bertolt Brecht y Piscator. La relación con Asja Lacis dejó una marca intelectual profunda en Benjamin, a la vez que era para él una historia de amor desdichado, ya que ella vivía en pareja estable con el también director de teatro Bernhard Reich, otro colaborador de Brecht.

Así Benjamin conoció al dramaturgo Bertolt Brecht con quien sostuvo contacto e intercambio de ideas durante todo el resto de su vida. Otros contactos intelectuales decisivos fueron los filósofos Ernst Bloch con quien compartió experiencias experimentales y posteriores publicaciones (Benjamin, 1995) y Georg Lukács. Con ambos sostuvo largas discusiones. Leyó Historia y consciencia de clase (1968), una recopilación de ensayos de Lukács que en aquella época y las décadas posteriores dio impulsos renovadores a las ideas que circulaban entre los intelectuales cercanos al marxismo. Todo ello, junto con la observación y el análisis de la convulsionada dinámica económica, social y política de la década de los años veinte, le hizo distanciarse de sus iniciales posiciones anarquistas y lo condujo hacia el materialismo histórico sin que por ello descartara las ideas filosóficas que había extraído del judaísmo.



5. Gershom Scholem

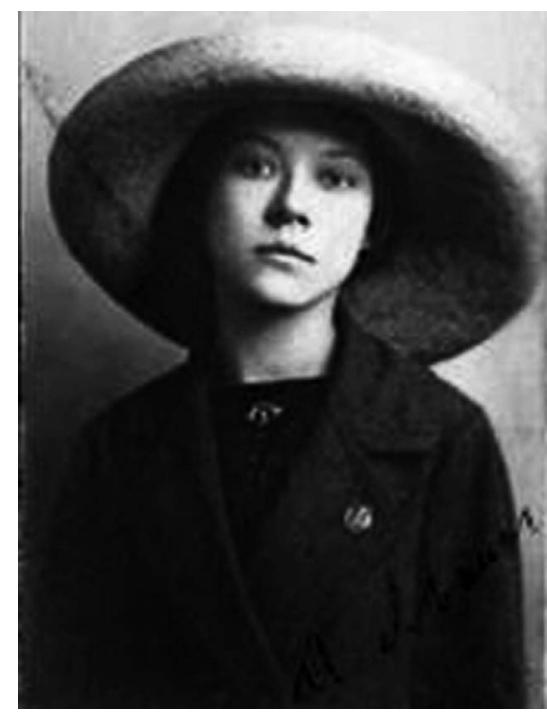

6. Asja Lacis 


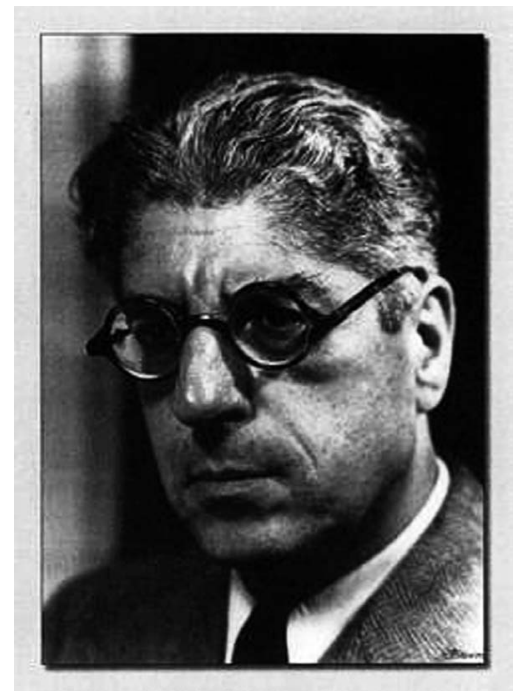

7. Ernst Bloch

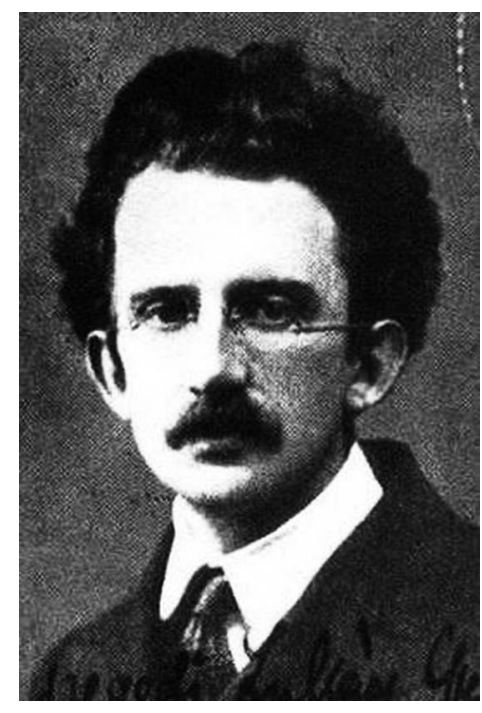

8. Georg Lukács

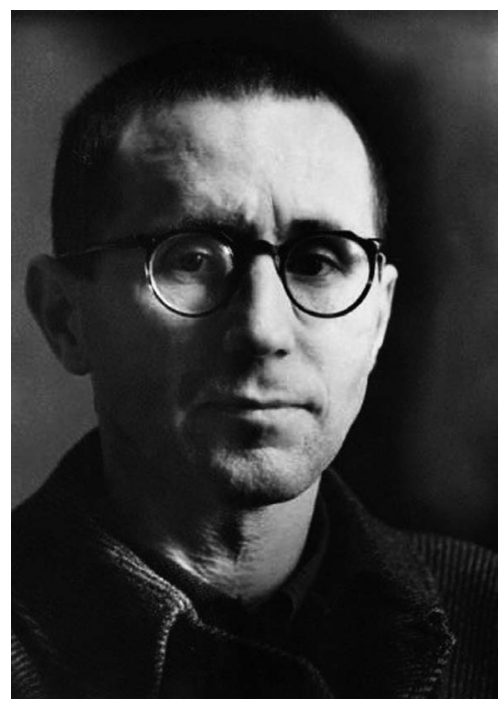

9. Bertolt Brecht

Así logró rebasar la tradicional concepción occidental lineal de la historia que es teleológica, la gran narración de un progreso que - ya sea en su versión iluminista dieciochesca o su versión socialista o comunista decimonónica - inexorablemente desembocaría, a través del avance tecno-científico, en un paraíso de la libertad, igualdad, fraternidad y prosperidad económica de todos los seres humanos.

Un punto central en el ideario de Benjamin son sus ideas estéticas que lo ubican cerca a la Bauhaus y a Brecht.

Los filósofos de la llamada Escuela de Frankfurt, particularmente Max Horkheimer y Theodor W. Adorno, lo ganaron como colaborador para su Institut für Sozialforschung, el Instituto para la Investigación Social en Frankfurt y la revista del mismo nombre que editaban. De hecho, escribió por encargo de esta revista su texto hoy más popular y leído, La obra de arte en la época de su reproductibilidad técnica.

Cuando los nazis asumieron el poder en Alemania Benjamin se vio forzado - como también Klee - a abandonar su patria. Como hombre identificado con la izquierda y además hijo de una familia judía tenía que ponerse a salvo. Emigró a Francia, pasando previamente varios meses en la casa de Bertolt Brecht en Svendborg, Dinamarca, donde el último vivía igualmente en exilio y donde se produjo un intercambio de ideas muy intenso entre los dos intelectuales.



10. Foto del pasaporte alemán de Walter Benjamin 
Los siguientes siete años - que iban a ser los últimos de la vida de Benjamin - los pasó trabajando en la Biblioteca Nacional de Paris en el proyecto de su monumental obra principal, Das Passagenwerk (1982a) - La Obra de los Pasajes, que iba a quedar inconclusa.

En 1940 condensó los principios filosóficos subyacentes a esa obra en sus Tesis sobre la Filosofía de la Historia (1971). Inmediatamente después tenía que huir de nuevo. Ya estaba en curso la Segunda Guerra Mundial y las tropas de la Alemania nazi estaban a punto de entrar en Paris; el gobierno francés firmó la capitulación y se instauró el llamado Gobierno de Vichy, un gobierno títere al servicio del Tercer Reich alemán. Benjamin recibió la ayuda de la Resistence, la clandestina resistencia antifascista francesa. Como muchos otros fugitivos huyó de los territorios ocupados por los alemanes hacia el sur, atravesando la parte de Francia gobernada por los colaboradores de los nazis; tuvo que viajar principalmente a pie, escondiéndose de día y caminando de noche por vías alternas rurales, con la esperanza de llegar a algún puerto en España o Portugal para tomar un barco hacia Nueva York, donde Adorno y Horkheimer, quienes le habían conseguido una visa, ya habían establecido nuevamente su Instituto para la Investigación Social y lo estaban esperando. Por un camino secreto en el bosque, en los Pirineos, cruzó la frontera hacia España y llegó al pueblo Port Bou. Inicialmente creía que se había puesto a salvo, pero la Guardia Civil franquista lo detuvo porque ese mismo día acababa a entrar en vigencia un acuerdo entre el recién instaurado gobierno francés pro-nazi y el del dictador español Francisco Franco según el cual los fugitivos iban a ser deportados y entregados a la Gestapo, la temible policía secreta nazi, lo que para Benjamin significaba la muerte segura en un campo de concentración. Ante esta situación se quitó la vida ingiriendo morfina.



11. Última foto de Benjamin, 1940, reseña policial en Port Bou 
Klee y Benjamin tenían de cierto modo vidas paralelas. Presenciaron los acontecimientos históricos de los primeros cuarenta años del siglo veinte con sus avances tecnológicos, sus profundos cambios culturales, el fatal desenlace en el fascismo y totalitarismo y los horrores de las dos más grandes guerras que la humanidad ha visto. Ambos, cada uno en su particular lenguaje, reconocieron eso con clarividencia e hicieron advertencia de ese peligro (que aún hoy acecha con renovada fuerza) y ambos sufrieron y murieron a causa de ello.

El abordaje teórico de esa problemática inmanente a la Modernidad occidental se convierte en objetivo central de la Escuela de Frankfurt (Horkheimer y Adorno, 1969/1994; Horkheimer, 1967/2012). A partir de la década de los años ochenta y noventa del siglo XX adquiere aún mayor vigencia ya que se ponen en el orden del día de muchos pensadores la discusión acerca de la crisis de la Modernidad, la llamada Postmodernidad, la Ecología, la Globalización, el tema de las fronteras y líneas divisorias entre culturas y territorios, las nuevas olas de migración a nivel global y las mutaciones psíquico-éticas de los seres humanos en la sociedad postindustrial (Lorenz, 1973; Laszlo, 1989; Huntington, 1996; Huntington, 2004; Berman, 2008; Sarrazin, 2010; Hobsbawm, 2011; Sloterdijk, 1983).

El vínculo entre Klee y Benjamin se condensa - como ya se señaló - en la pequeña obra pictórica de Klee, llamada Angelus Novus. A comienzos de los años veinte Benjamin, probablemente al visitar una exposición del ya famoso pintor Paul Klee, adquirió esta obra y ella tuvo un profundo impacto en él: tuvo gran transcendencia en la evolución de sus ideas y metodologías a partir de ese momento.

Ese cuadro es el núcleo alrededor del cual se articula lo que sigue. Es un caso particular, basado en un hecho anecdótico que permite ejemplificar una relación horizontal, no hegemónica, entre pintura y filosofía.

\section{La mónada}

A comienzos del siglo XVIII el filósofo alemán Gottfried Leibniz (1646-1716) desarrolló en una de sus últimas obras, La monadología, publicada en 1715, el tema de la mónada que aparece en el pensamiento occidental desde la antigüedad clásica. Los pitagóricos relacionaban la mónada con la geometría y la cosmogonía; también está presente en la filosofía de Platón y más tarde, en el Renacimiento, en el pensamiento de Giordano Bruno (1548-1600) y también en el ideario del filósofo inglés Henry More (1614-1686). La idea de la mónada se puede resumir en la siguiente frase: en el ente más simple y originario está contenido el universo. Leibniz sostenía que el ente más simple y originario es el espejo del universo.

A finales del siglo XVIII, el poeta y escritor alemán Johann Wolfgang von Goethe, quien también se dedicaba a las ciencias naturales, adoptó esa idea para sus estudios de botánica y de morfología de las plantas; construyó la idea de la Urpflanze - la Planta Originaria o Planta Arquetípica en la que estaría resumido todo el cosmos botánico. 
12. Representación de la Urpflanze, según las ideas de Goethe; xilografía de Pierre Jean François Turpin, 1837



Benjamin, quien era un gran estudioso y conocedor de la multifacética obra de Goethe, acogió de él la idea de la mónada, la hizo suya, la adoptó de manera novedosa a sus estudios culturales y la aplicó en su obra principal, Das Passagenwerk (Benjamin, 1989) La obra de los Pasajes.

En ese sentido las presentes reflexiones no solamente giran alrededor del pensamiento filosófico de Benjamin y la pintura de Klee sino tratan de seguirles también

204 metodológicamente; pretenden hacer visible mediante el ejemplo particular de la relación entre las obras de estos dos intelectuales la siguiente tesis: existe una relación entre pintura y filosofía no solamente en el sentido de que ambas se relacionan en cuanto brotan de un mismo sustrato histórico y cultural que los puede convertir en fenómenos paralelos, no solamente en cuanto la filosofía analiza el arte a través de la estética o la hermenéutica convirtiéndolo en su objeto de estudio. Existe una relación entre arte/pintura por un lado y filosofía por el otro que es horizontal recíproca, a nivel de ojos. Esa relación de fecundación mutua no suele hacerse explícita con frecuencia. Muchas veces no llega ni siquiera a la consciencia de los participantes de esa relación. Pero podría ser demostrada en muchísimos casos.

El Angelus Novus de Klee fue decisivo para las Tesis sobre la Filosofía de la Historia de Benjamin (1971) que a su vez condensan la esencia filosófico-histórica de su obra principal, Das Passagenwerk. Es interesante que en esa relación horizontal entre ambas, el componente artístico con frecuencia tenga la primera palabra o lleve la delantera como sucedió en el caso de Klee y Benjamin: del arte a la filosofía. 
Y este es el caso del arte vanguardista de la primera mitad del siglo XX en general, que de hecho anticipó de manera lúcida los debates que entran en vigencia entre los filósofos de la postmodernidad. Para la filosofía la crisis del sistema cultural de la Modernidad occidental se vuelve tema central solo en el último tercio del siglo XX, aparte de algunas excepciones (Horkheimer y Adorno, 1969/1994; Horkheimer, 1967/2002).

La particular manera de los artistas de relacionarse con el mundo, su específico modus operandi - diferente al de la ciencia tradicional positivista e incluso diferente al usual raciocinio filosófico - implica que ellos muchas veces muy tempranamente perciban y plasmen en sus obras aquello que solamente más tarde es dado a ser reconocido por los teóricos. Se trata de la capacidad de los artistas de salir - mediante el aguzamiento de su sensorium - de los acostumbrados esquemas perceptivos y de abordar espacios de la realidad aún no explorados para incorporarlos, mediante actos y acciones de transformación de materiales físicos o del entorno cultural, en algo humanamente aprehensible, poniendo para ello en acción sus fuerzas emocionales y capacidades sensibles y racionales en conjunto (Bambula Díaz, 2014).



13. Klee, 1930, Tiene cabeza, mano, pie y corazón, acuarela y pluma sobre algodón, sobre cartulina sobre placa de aglomerado. Pintura que Klee realizó para sus estudiantes en la Bauhaus.

Esto no implica que los artistas expresen estas concepciones siempre de manera representacional, en imágenes narrativas, figurativas. Al contrario: muchas veces sus realizaciones interpelan el statu quo - ya sea con sutileza como Klee o con radicalismo provocador de Duchamp y los dadaístas y surrealistas - de manera performativa mediante actos y acciones, pero siempre a través de las formas. 
Esta especial capacidad del artista tiene que ver con la manera como él - en nuestro caso Paul Klee como pintor - hace uso holístico de su sensorium, que funciona como un sismógrafo ante lo real, lo que permite aprehenderlo en su dimensión profunda y su complejidad de manera intuitiva mediante una concentración exaltada de todos los sentidos en su conjunto.

\section{Angelus Novus}

Cuando Benjamin en 1921 vio el pequeño cuadro de Paul Klee, titulada Angelus Novus, le causó profundo impacto y lo compró. La imagen se estableció en su mente como una alegoría alrededor de la que se fueron condensando, a lo largo de su vida, las ideas más significativas de su pensamiento en forma visual.

El cuadro - como objeto físico - acompañó a Benjamin durante toda su azarosa vida. En 1940, antes de partir en su huida, lo resguardó en manos de George Bataille, quien trabajaba en aquel entonces en la Biblioteca Nacional de París. (También entregó a Bataille el manuscrito inconcluso de la Obra de los Pasajes). Sabemos que Benjamin quiso legar el Angelus Novus a su amigo Gershom Scholem.

Durante mucho tiempo no se conocía el paradero del cuadro y se temía que se había perdido en las turbulencias de la guerra. Ahora se sabe que llegó a las manos de Theodor Adorno, quien finalmente lo entregó a Gershom Scholem. Hoy se encuentra en el Museo de Israel en Jerusalén.

Benjamín vio en el Angelus Novus una alegoría que condensaba una muy particular concepción de la historia, que poco a poco - y bajo el impacto de los acontecimientos histórico-políticos de los años veinte y treinta - tomaba forma en su mente y adquirió cada vez más importancia, específicamente para el proyecto de la Obra de los Pasajes. A partir de 1927 los Pasajes se convirtieron en el eje rector de su actividad intelectual. Era un proyecto mayor de análisis y crítica del paradigma cultural de la Modernidad occidental que implícitamente sugiere y aplica una epistemología alternativa. Esta nueva epistemología iba a visibilizar aspectos de la Modernidad occidental que el tradicional modo de hacer historia, en forma de narración lineal, no permite ver.

Este aspecto es importante en cuanto parte de un principio de estética, que se evidencia particularmente en el arte de vanguardia: la unidad inseparable de forma y contenido, o sea - la forma - en ese caso la de proceder en la investigación y de organizar el conocimiento y el conocimiento mismo que esta nueva metodología conlleva. En 1940, durante las últimas semanas de su vida, Benjamin alcanzó a explicitar esto de manera sintética en sus Tesis de filosofía de la historia (1971) su último escrito y de cierta manera su testamento intelectual.

Cuando Benjamin en 1921 compró el Angelus Novus, Klee ya tenía 40 años. Era un pintor famoso y reconocido, sus exposiciones tuvieron gran éxito. Esa aprobación social era un estímulo para él. Entró en una fase de intensa productividad. Pero era 
una época políticamente muy turbulenta y Klee tenía sus ideas al respecto. Sabía que el éxito en el arte suele ser efímero y no depende únicamente de la calidad de las obras. Se sentía insatisfecho con ese éxito, porque sentía que aquellos que le convertían en celebridad no le entendían y que en realidad no les importaba lo que significaba su obra (Partsch, 1991).

El público - ávido de lo exótico y de la extravagancia del 'arte moderno' estaba sobre todo interesado en las obras de Klee de la época anterior a la guerra. Klee había realizado viajes al Norte de África y las obras que resultaron de esos viajes gozaban de la aceptación y legitimación de los coleccionistas más atrevidos, interesados en invertir sus recién acumuladas fortunas (amasadas con base en el gran negocio de la guerra), de manera segura (Partsch, 1991). Pero del impacto visual del viaje a Noráfrica hay una línea que conduce a Klee directamente hacia sus abstracciones posteriores que empiezan a cumplir una función didáctica en la Bauhaus:



14. Klee, Vista de Kairuan, 1914, acuarela



15. Klee, Domos rojos y blancos, acuarela, 1914 




16. Klee, Arquitectura, 1923

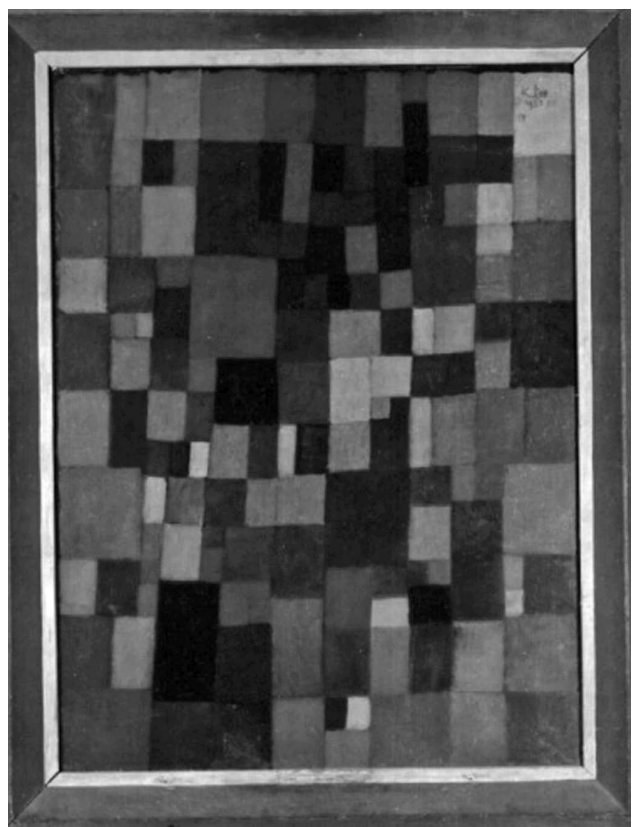

17. Klee, Harmonía de cuadriláteros, 1923

El cuadro Angelus Novus, que aquí nos interesa en relación con Walter Benjamin, no hace parte de esa línea. Fue pintado en la época inmediatamente después de la Guerra, o sea, según nuestra estimación entre 1919 y 1920, poco antes de la vinculación de Klee a la Bauhaus. Eran años convulsionados política- y económicamente. En 1918 había terminado la Primera Guerra Mundial con la derrota de Alemania. Miles de jóvenes habían muerto por una idea nacionalista que a la postre resultó un engaño. Había hambre y desespero.

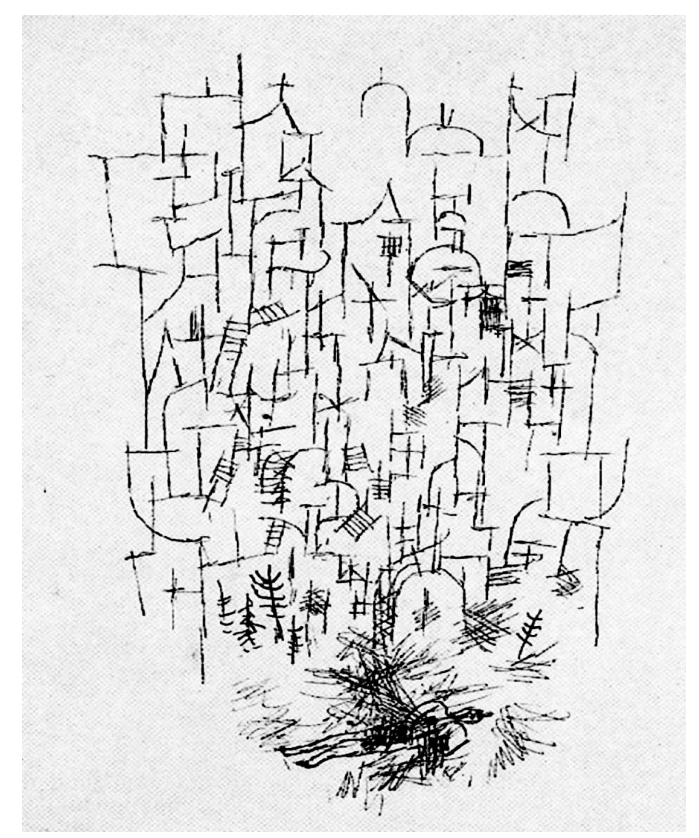

18. Klee, La muerte por la idea, 1915, litografía a la pluma 
La terrible situación social desembocó en la Revolución de Noviembre y convirtió Alemania de una monarquía imperial en una república. La guerra y la conmoción social que le seguía conllevaron también en Klee la reflexión sobre el curso de la historia.

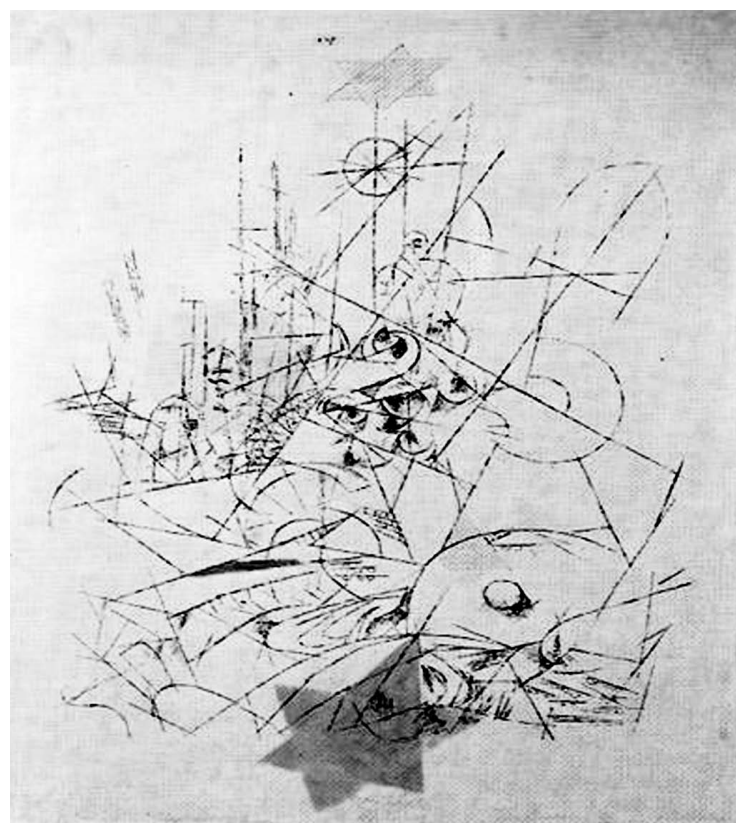

19. Klee, Destrucción y esperanza, 1916, litografía y acuarela

El origen del cuadro Angelus Novus en medio de un acontecer histórico-político convulsionado es de relevancia ya que arroja luz sobre el misterio de su relación con el pensamiento de Benjamin. Éste lo interpretaría luego como alegoría históricofilosófica.

Todavía en 1914, al inicio de la Guerra, Klee - como muchos intelectuales - había puesto esperanzas en ella en el sentido de una renovación económica e ideológica de Alemania. Pero muy pronto cambió totalmente de opinión y adoptó una posición pacifista radical; se refugió en su propia subjetividad, en una especie de exilio interno, decidió no realizar más cuadros directamente sobre la guerra.




Esto sin embargo le permitía trabajar con creatividad, exteriorizando sus ideas en forma cifrada. En 1917, en plena guerra, Klee había sido llamado a filas. A raíz de la intervención de su padre no se le había enviado al frente. Podía trabajar como escriba en una escuela de pilotos y no necesitaba interrumpir su trabajo de pintor (Partsch, 1991).

Al final de la guerra Klee temía el estallido de una revolución y ésta efectivamente se produjo. En la ciudad de Múnich, un lugar de intensa actividad artística vanguardista, donde Klee se encontraba y donde pocos años antes había nacido la asociación de pintores expresionistas El jinete azul, tomó el poder en abril de 1919 un gobierno revolucionario de izquierda e instauró la República de Consejos Muniquesa. Klee era escéptico y temeroso ante lo político. Pero ocupaba justamente en ese momento el puesto de Secretario de la organización de todos los artistas de vanguardia de la ciudad, la Nueva Secesión. El nuevo gobierno municipal miraba con buenos ojos el arte moderno y Klee fue invitado en abril de 1919 a formar parte del Comité de Artistas Revolucionarios. Dejó atrás sus temores y aceptó la invitación con entusiasmo (Partsch, 1991). La República de Consejos Muniquesa fue derrotada muy pronto; ya en mayo 1919, las tropas gubernamentales enviadas desde el resto del país cercaron y tomaron la ciudad; había fusilamientos masivos y Klee tenía que ponerse a salvo en Suiza.



21. Represión contra los revolucionarios de la República de Consejos Muniquesa, foto histórica de 1919

Una carta de Klee escrita en mayo 1919, inmediatamente después de la derrota de la República de Consejos Muniquesa, demuestra una posición estética muy cercana a lo que serían más tarde las ideas de Benjamin, particularmente las que iba a desarrollar respecto a los efectos que la reproducción técnica tiene para la noción y funcionalidad social del arte. Klee escribió: 
Aunque desde el comienzo parecía que esta república comunista no iba a durar mucho tiempo, brindó no obstante la oportunidad de examinar la posibilidad subjetiva de existir en semejante forma de sociedad. No puede decirse que no haya tenido ningún resultado positivo. Naturalmente, un arte exageradamente individualista no es apto para ser disfrutado por la colectividad, es un lujo capitalista. Pero creo que somos más que meras curiosidades para snobs adinerados. ... El efecto fructificador de nuestro ejemplo tendría lugar, canalizado de otra manera, sobre una base más amplia... Este nuevo arte podría introducirse luego en los oficios y provocar un gran florecimiento (Partsch, 1991, p. 42).

Poco después aceptó el llamado a la Bauhaus. Allí - junto con Wassily Kandinsky, Oskar Schlemmer, László Moholi Nagy y otros - trató de poner en práctica estas ideas mediante la pedagogía, de manera experimental. La Bauhaus era una escuela de arte novedosa, cargada de energía y creatividad y de cierta manera - a pesar de sus tensiones internas - revestía características de una congregación con ideales orientados al futuro. Era un auténtico invernadero de aquel nuevo arte al que Klee se había referido en su carta de 1919.

Son las ideas que desarrolla Benjamin más de una década después, en su ensayo sobre la obra de arte en la época de su reproductibilidad técnica. Benjamín pensaba que el arte ya debía ser concebido en su relación con la sociedad de masas. No compartía la concepción tradicional del arte que a partir de un enfoque elitista se opone a su masificación, considerando que solo sea accesible al individuo singular.

Para Benjamín el avance tecnológico no implica la perdición del arte, aunque sí un profundo cambio en su funcionalidad social. Según la tesis marxista los avances de tecnología, es decir de los medios de producción y las fuerzas productivas, conllevan la necesidad de un cambio de las relaciones de producción. Por eso entran en una tensión con éstas últimas mientras se mantienen estáticas e inamovibles. Benjamín explora esa tesis en una nueva dirección. Para él la recepción estética en la disipación (que se hace posible gracias a la tecnología, particularmente los medios de comunicación, y que implica la pérdida de lo que llamó "el aura" de la obra de arte) genera un profundo cambio cultural: el cambio del modo de percepción y con ello el cambio del sensorium. Estas tesis las explicita sistemáticamente solo en 1935-36. La Bauhaus, con Klee como uno de sus principales maestros, practicó esa idea del nuevo sensorium desde 1919 y la explicitó teóricamente en detalle, desde el punto de vista del arte y con fines pedagógicos.

El cuadro Angelus Novus no pertenece al grupo de obras abstractas en los que se fundaba gran parte del éxito de Klee a finales de la segunda década; pertenece a un número de obras de carácter más íntimo, en los que se hace uso de formas que podríamos calificar de infantiles y cuyos temas revisten un carácter mítico y misterioso cuyo significado se encuentra cifrado. 


\section{Los pájaros en picada. Acerca del locus enuntiationis}

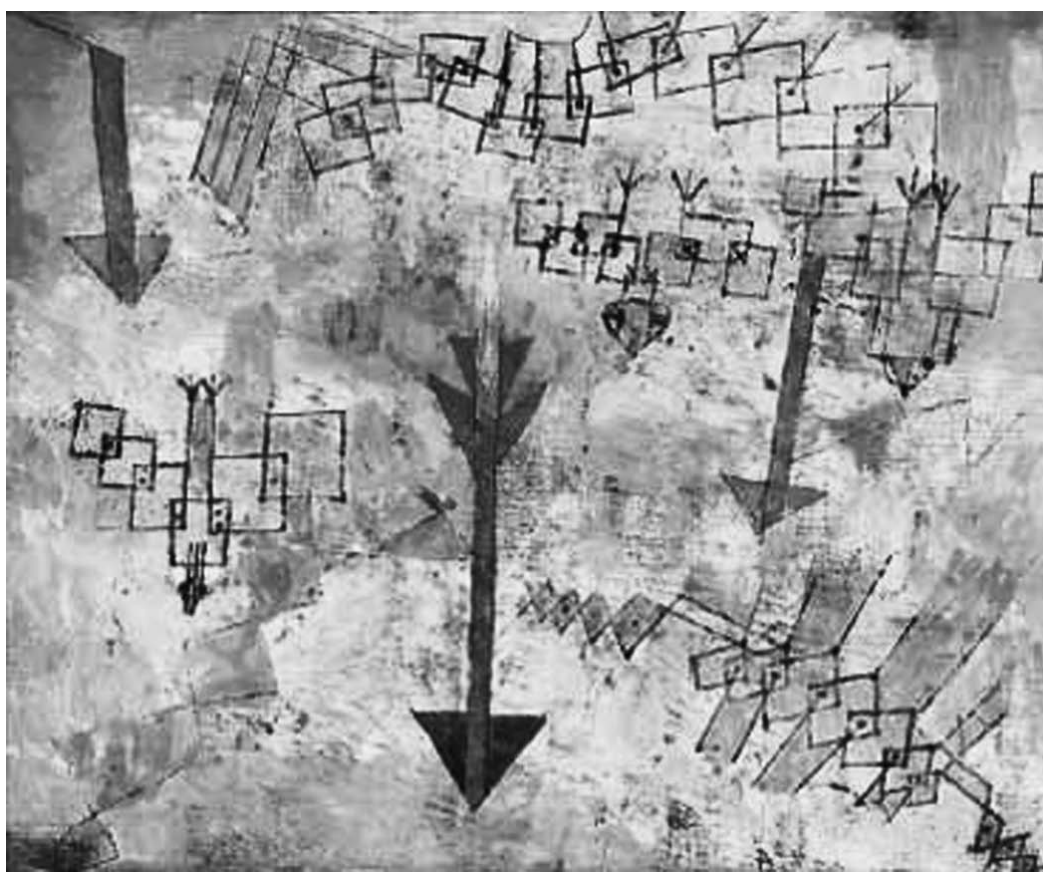

22. Klee, Pájaros tirándose en picada, 1919, técnica mixta

Un tema recurrente en ese contexto de obras se relaciona con el volar - una idea que había conquistado la mente de Klee desde tiempos atrás y que había estado presente en sus meditaciones. Ya en 1905, a los 26 años, había tratado el tema en dos aguafuertes: Fénix anciano y El héroe con un ala.



23. Klee, El héroe con el ala, 1905 , aguafuerte 
A este último había añadido el siguiente comentario: "Provisto por la naturaleza de un ala se imagina que estaba destinado a volar, lo cual es causa de su perdición" (Partsch, 1991.p.41). Luego escribe en su diario:

Este ser humano, a diferencia de los divinos, nacido con una sola ala de ángel, no cesa de hacer intentos de volar. El que se rompa brazos y piernas, no está impidiendo de seguir siendo fiel a la idea de volar (Diarios, 585, citado según Partsch, 1991, p.41).

En 1906 había anotado: "Sueño.Volé a casa, donde está el principio..." (Diarios, 748, citado según Partsch, 1991.p.41). Una década después, en 1915, ante el horror de la guerra, escribe:"Para salir de mis ruinas, tenía que volar.Y vole”" (Diarios, 952, citado según Partsch, 1991.p.41).

En la Escuela de Pilotos de Gersthofen, donde en 1917 prestaba su servicio de guerra, una de sus tareas era fotografiar los aviones precipitándose al vacío - una novedad tecnológica espectacular en aquella época. De hecho, inicialmente la nueva tecnología de la aviación fue utilizada para vuelos de reconocimiento sobre zonas de algún interés colonial o territorio enemigo.



24. Un avión alemán sobrevuela las Pirámides de Guiza en 1917, imagen captada desde otro avión. Foto histórica 


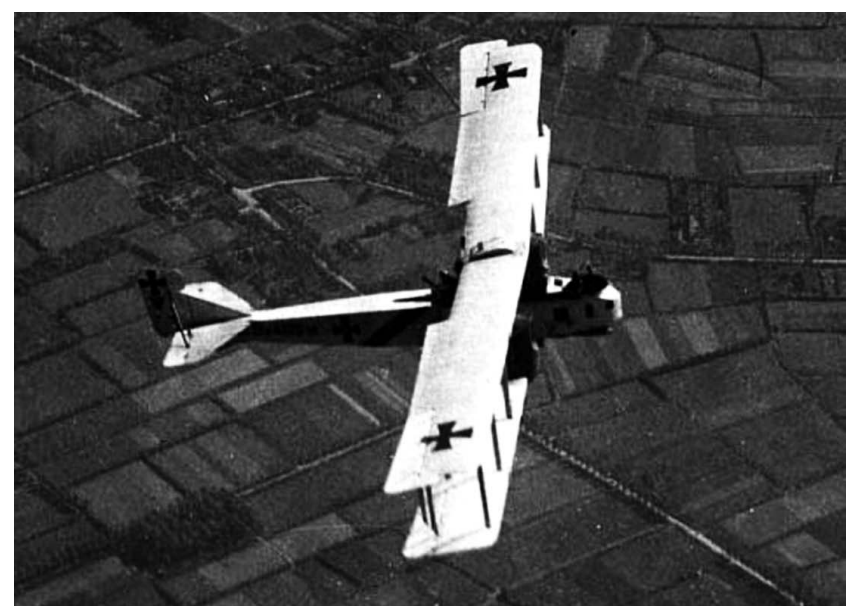

25. Avión alemán volando sobre Inglaterra durante la Primera Guerra Mundial. Foto histórica, captada desde otro avión.

Muy pronto la aviación se utilizó también y principalmente para batallas aéreas y para bombardeos. Para ello se requería gran destreza y valor de parte de los pilotos que tenían que hacer maniobras tirándose en picada sobre su objetivo de ataque para levantar de nuevo el vuelo en el último instante antes de estrellarse.


26. 1915: El piloto de caza Max Immelmann, 'héroe' de la Primera Guerra Mundial, fue llamado 'el Águila de Lille' por su habilidad para realizar maniobras en picada en los ataques aéreos contra Francia. Foto histórica

27. Un año después, en 1916, solo quedaron los restos de su avión. Foto histórica- 
En los cuadros de Klee empiezan a aparecer misteriosos pájaros, algunos cayendo en picada, como en El mito de la flor, en Pájaro cayendo o en Pájaros tirándose en picado y flechas entre otros.

28. Klee, El mito de la flor, 1918, acuarela sobre indiana imprimada de tiza sobre papel periódico sobre cartulina, ribeteado de purpurina
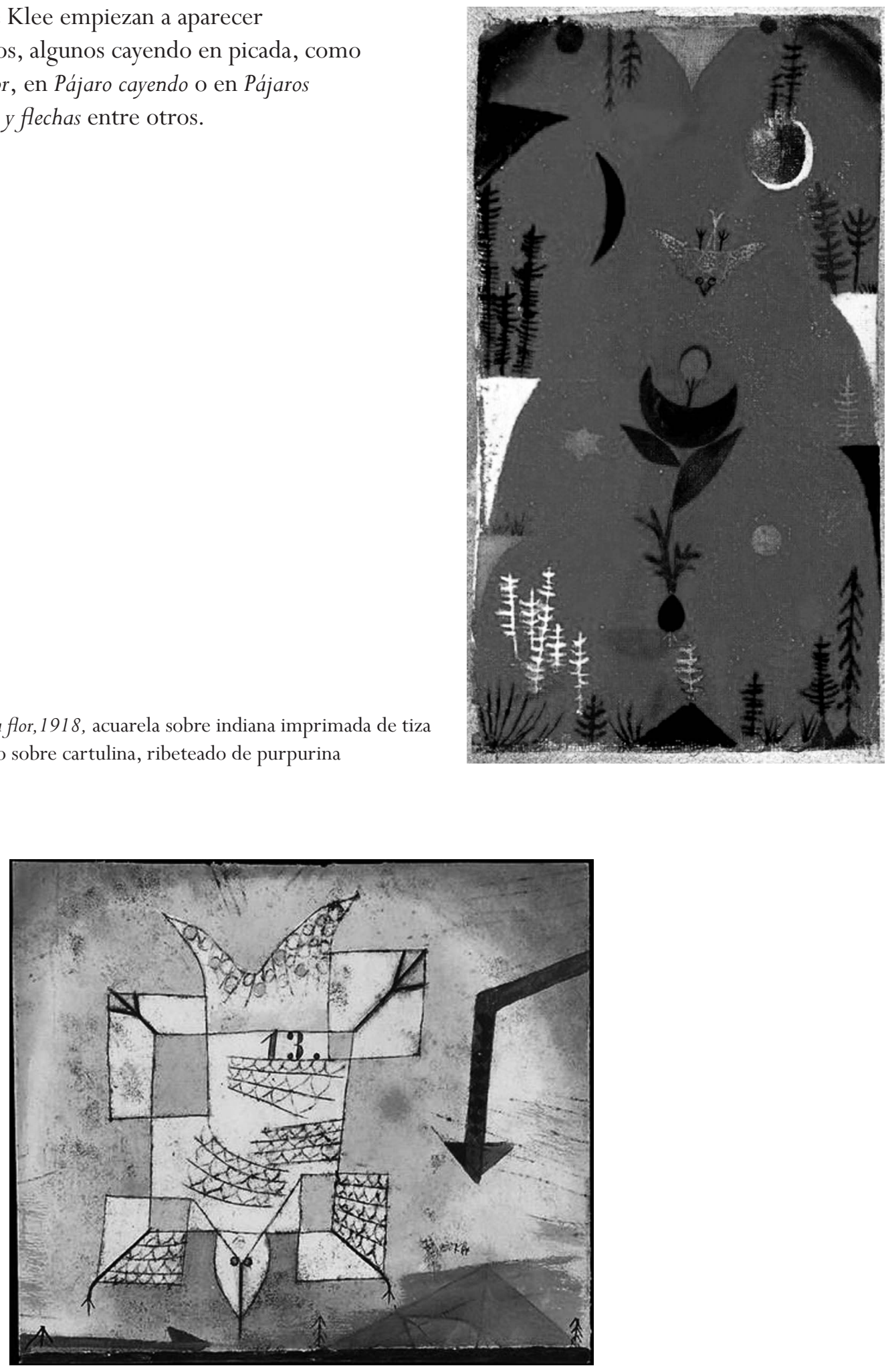

29. Klee, Pájaro cayendo, 1918, acuarela y tinta de imprenta sobre papel, bordeado con tinta, montado sobre cartón 
En la escuela de pilotos realizó también un cuadro titulado Con el águila. Allí se encuentra un pájaro, como si fuera un avión de papel plegado, con las alas ya extendidas para emprender el vuelo, posado encima de un arco negro, curvado sobre un enorme ojo que observa en medio de un paisaje infantil poblado de arbolitos, casas y animales. Klee quiso conservar esta obra para sí - un indicio de la importancia que tenía para él.

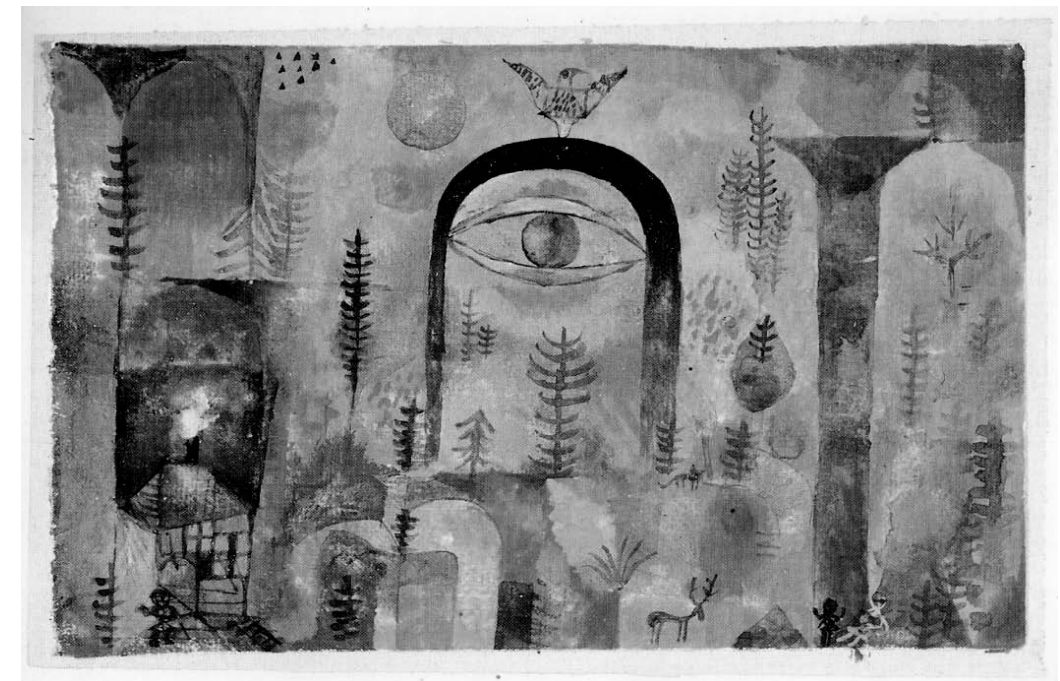

30. Klee, Con el águila, 1918, colores al agua sobre base roja sobre papel ingres imprimado con tiza, con soporte de papel satinado verde sobre cartulina.

Para entender bien lo que aquello significa hay que tener en cuenta que el nuevo invento tecnológico de la aviación que se juntaba con él de la fotografía y del cine, tuvo efectos en el arte, no solamente en el sentido simple de agregar a la tradicional perspectiva central renacentista una perspectiva de pájaro - algo que efectivamente ocurrió, sino - y eso es lo que aquí nos interesa - en cuanto llamó la atención sobre un recurso artístico, el de la posibilidad de asumir subjetivamente diversos puntos de visualización, como por ejemplo una visión globalizante o una visión de máxima cercanía, perspectivas que favorecen la abstracción, como demuestran varias obras de Klee, entre ellos Separación vespertina, Lugar afectado y Caminos principales y caminos laterales.

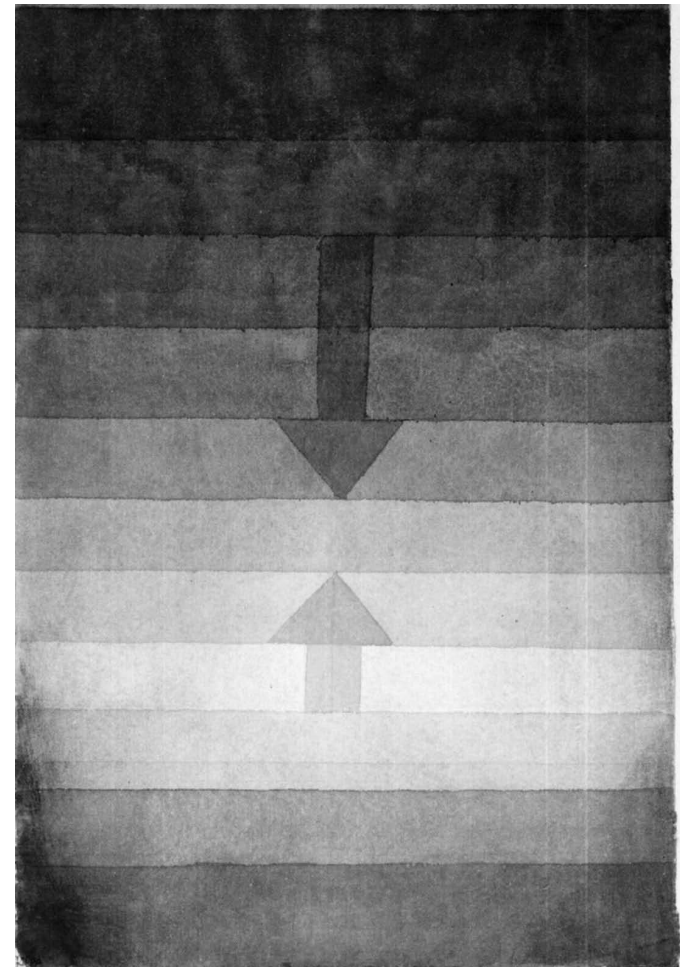




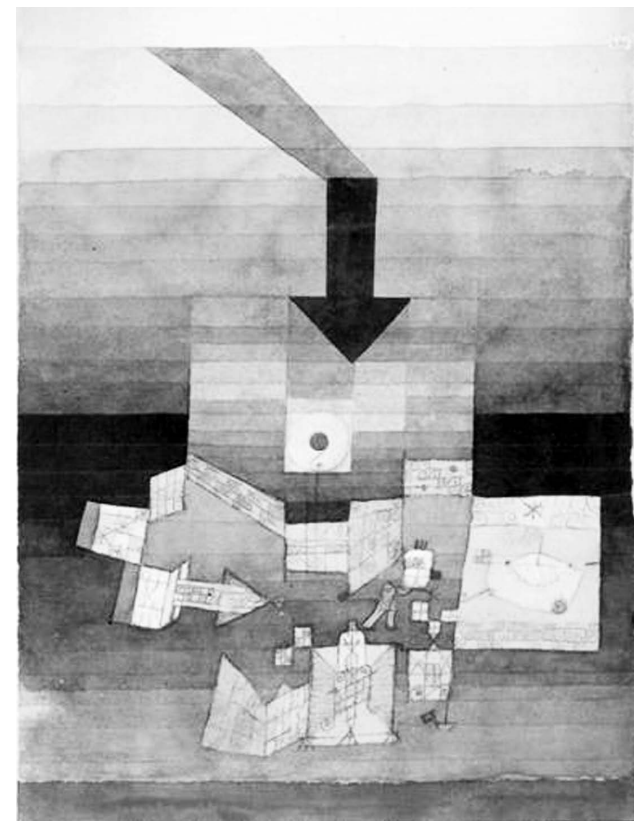

32. Klee, Lugar afectado, 1922, acuarela, dibujo a pluma con tinta china sobre lápiz, sobre papel sobre cartulina.

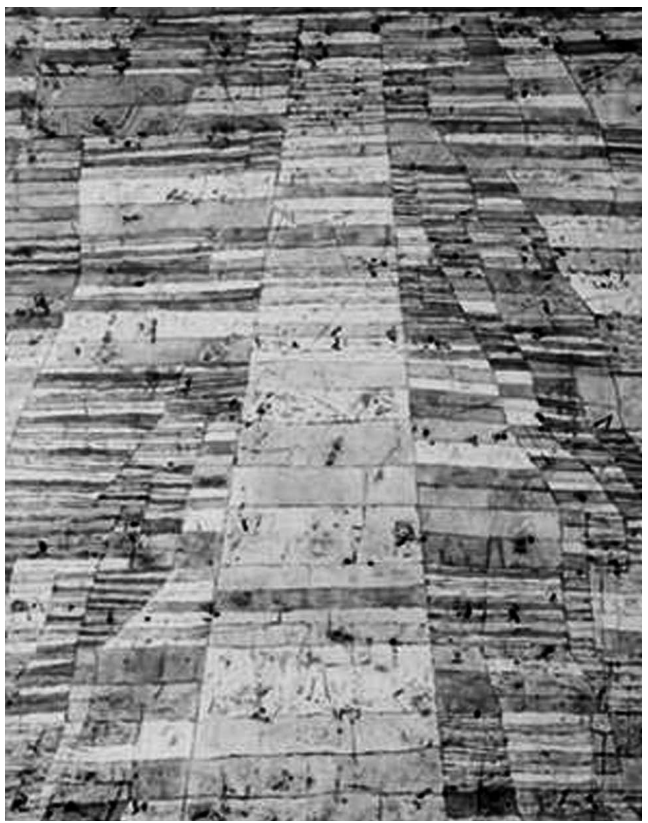

33. Klee, Caminos principales y caminos laterales,

En la misma época, la década de los años veinte, Klee empieza a extender su interés desde la perspectiva 'macro', a la 'micro': le empieza a interesar la mirada, para decirlo así, por la lupa o por el microscopio.

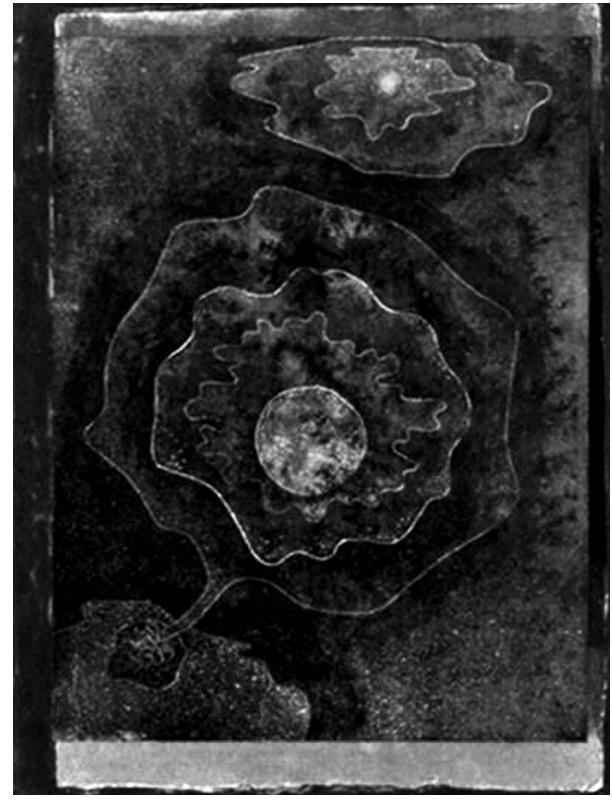

34. Klee, Curioso a la manera vegetal, 1929, colores al agua sobre acuarela sobre papel imprimado de negro sobre papel acuarelado sobre cartulina.

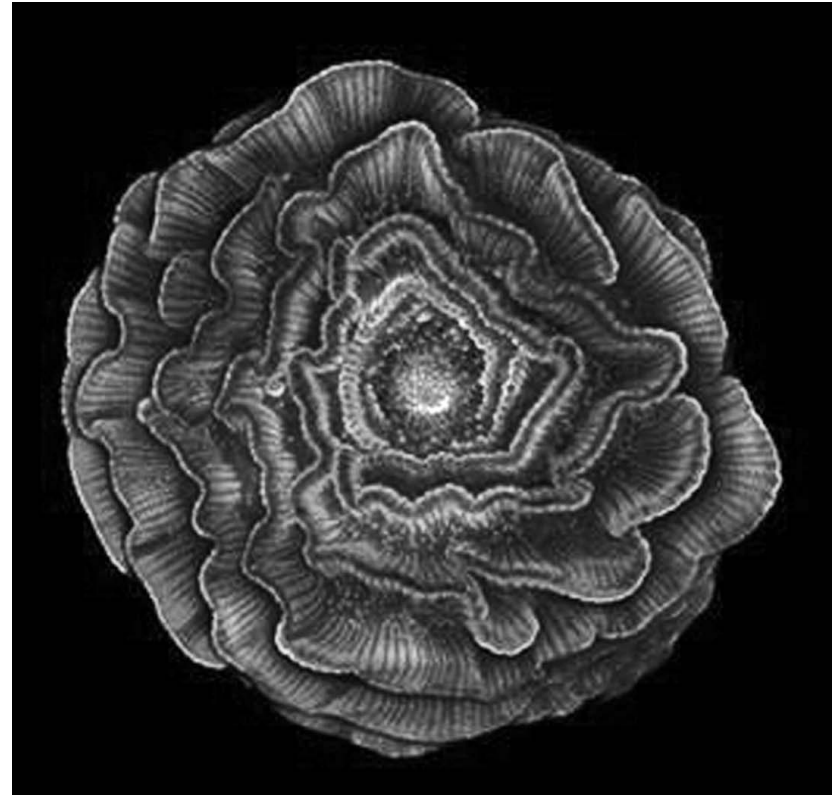

35. Mirada por el microscopio: La semilla de la flor delfín. Foto de Masoumeh "Sahar" Khodaverdi, Universidad de Tabriz, Tabriz, Iran. La imagen estuvo entre las diez ganadoras del concurso internacional de fotografía digital “Olympus Bioscape”2012. 

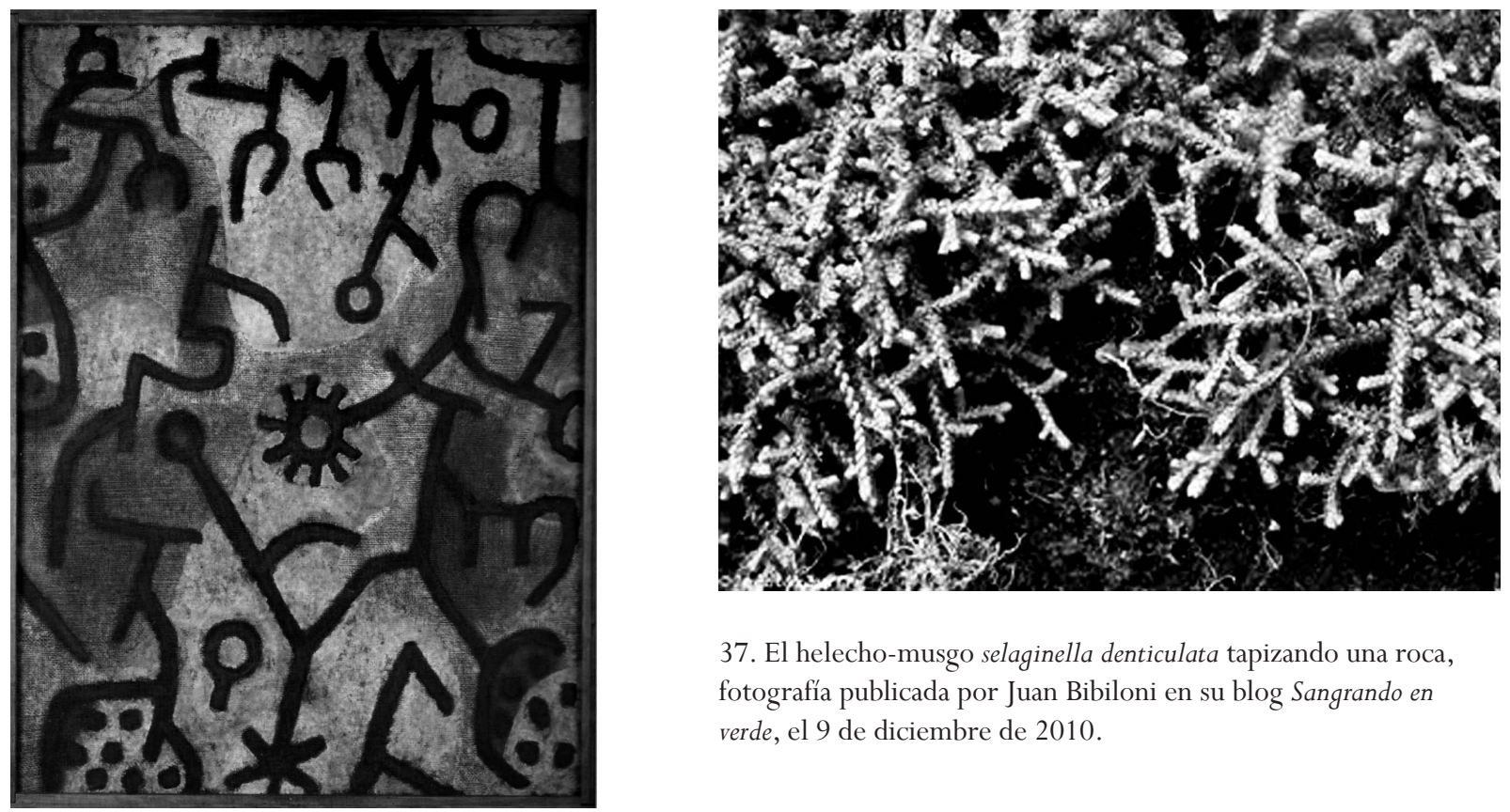

37. El helecho-musgo selaginella denticulata tapizando una roca, fotografía publicada por Juan Bibiloni en su blog Sangrando en verde, el 9 de diciembre de 2010.

36. Klee, Flora en el peñasco, 1940, óleo sobre temple sobre yute

El interés de las vanguardias artísticas de la primera mitad del siglo XX en la problemática del punto de visualización ha sido hace tiempo atrás objeto de numerosos estudios y análisis; el ejemplo más conocido es el cubismo, y desde luego se relaciona también con la nueva tecnología visual del cine; la cámara fue un dispositivo que impulsó la conciencia también en las otras artes acerca de la relatividad del punto de visualización y la posibilidad del montaje de diferentes enfoques.

En 1920, año de su vinculación a la Bauhaus, Klee manifestó lo siguiente en relación con esta problemática:

Antes se describían las cosas que uno veía sobre la tierra, que uno veía con gusto o que uno no hubiera querido ver. Ahora la realidad de las cosas visibles se hace patente, dando expresión a la creencia de que, en relación con la totalidad del mundo, lo visible es solo un ejemplo aislado, y de que las otras verdades en su mayoría permanecen latentes. Las cosas se manifiestan en un sentido amplificado o multiplicado, contradiciendo a menudo a las experiencias racionales del pasado. Se aspira a una substancialización de lo casual (Paul Klee en fragmentos, 15 marzo 2010, párrafo 7).

No es coincidencia que justamente en aquella época, alrededor de 1922, también en la literatura se subvierte el tradicional discurso literario. 1922 es al año de la publicación del Ulyses de James Joyce (1976) con su forma narrativa del stream of consciousness. A la vez - inspirados en la gran novedad de la época, el cine, y su método de montaje - 
aparecen obras literarias como la novela Manhattan Transfer de John Dos Passos (1984) que está estructurada como un collage de relatos fragmentarios con diferentes puntos de vista narrativos que se juntan, a modo de mosaico o rompecabezas en un retrato de la gran metrópoli.

Mientras esto sucedía, en las ciencias y en la historiografía aún seguían intactos y prácticamente sin ser cuestionados los enfoques tradicionales: omniscientes, unívocos y con pretensión de objetividad. La teoría de la relatividad expuesta por Einstein en 1905 se demoraría aún mucho para tener repercusiones epistemológicas interdisciplinarias.

En el campo de la praxis estética, en cambio, ya estaba en el orden del día la consciencia acerca de la relatividad del locus enuntiationis, el punto de visualización / punto de vista / point of view. Benjamin es el primero que aplica esta idea fuera del campo de las artes, en su Obra de los Pasajes, como una metodología que tiene en cuenta la subjetividad y la diversidad de los puntos de vista. También Mijaíl Bajtin, más o menos en la misma época, se interesa por esa problemática en relación con la literatura: la llama polifonía, pero solamente la registra y analiza en la literatura, particularmente en la obra de Dostoievski, pero no aplica esto como metodología en sus investigaciones teóricas (Bajtin, 1986).

La temática del locus enuntiationis es hoy - ante los diálogos y/o conflictos interculturales que surgen a raíz de la globalización - un tema epistemológico de candente actualidad para los estudios culturales, las ciencias sociales, la psicología y las humanidades, particularmente en la investigación cualitativa y los nuevos paradigmas epistemológicos, que están surgiendo. En las ciencias naturales llamadas "exactas" o "duras" sigue hegemónico y poderoso el enfoque omnisciente unívoco, aunque también allí empiezan a emerger intentos de cambio de paradigma ( Fried Schnitman, 1994). Esto ya había sido abordado y explorado décadas atrás por los artistas y escritores de las vanguardias de la primera mitad del siglo XX.

Todos estos pensamientos y acontecimientos resultan de gran interés en relación con las ideas que Benjamín desarrollaría respecto a la historia y la investigación cultural y que para él se condensaban alegóricamente en el cuadro Angelus Novus.

En las Tesis de filosofía de la historia de 1940 (1971) Benjamín lo hizo explícito con la referencia a "un cuadro de Klee que se titula Angelus Novus" (Benjamin, 1971, p. 82):

Se ve en él un ángel al parecer en movimiento de alejarse de algo sobre lo cual clava la mirada. Tiene los ojos desencajados, la boca abierta y las alas tendidas. El ángel de la historia debe tener ese aspecto. Su cara está vuelta hacia el pasado. En lo que para nosotros aparece como una cadena de acontecimientos, él ve una catástrofe única, que acumula sin cesar ruina sobre ruina y se las arroja a sus pies. El ángel quisiera detenerse, despertar a los muertos y recomponer lo despedazado. Pero una tormenta desciende del 
paraíso y se arremolina en sus alas y es tan fuerte que el ángel no puede plegarlas. Esa tempestad lo arrastra irresistiblemente hacia el futuro, al cual vuelve las espaldas, mientras el cúmulo de ruinas sube ante él hacia el cielo. Tal tempestad es lo que llamamos progreso (Benjamin, 1971, p.82).

Benjamín se identificaba con la alegoría de ese ángel que solo puede visualizar el pasado que cae en ruinas, mientras el progreso, arremolinándose contra sus alas como una poderosa tormenta, lo arrastra irresistiblemente hacia un futuro que no es visto por él, que está a sus espaldas, que es desconocido.

Hay allí un elemento de la tradición profética judaica que hace repensar a Benjamín la historia desde una perspectiva distinta a la moderna occidental. El judaísmo prohíbe investigar el futuro. La Tora y la plegaria instruían, en cambio, en cuanto a la memoria. Para Benjamin no es posible recuperar el pasado en su totalidad. Dice: "La verdadera imagen del pasado pasa súbitamente. Solo en la imagen, que relampaguea de una vez para siempre en el instante de su cognoscibilidad, se deja fijar el pasado." (Benjamin, 1971, p.79)

La imagen fugaz del pasado sirve, sin embargo, para mantener la esperanza, ya que la historia ha sido construida sobre el horror, sobre la opresión y la barbarie.

Hay un paralelo a esto, un ejemplo entre muchos que con seguridad deben existir en las diferentes culturas no occidentales y no modernas del mundo y que - como debe suponerse - ni a Benjamín ni a Klee les era conocido. Proviene de otra cultura diferente a la de la Modernidad occidental, una cultura indígena suramericana: según las observaciones del antropólogo Víctor Daniel Bonilla ${ }^{3}$ para el pueblo indígena nasa, en Colombia, el futuro no se encuentra 'adelante', como en la cultura occidental, sino 'atrás', ya que uno no lo puede ver ni conocer. El pasado, en cambio, se encuentra 'adelante' ya que es conocido, es visualizado (Bambula Díaz, 1993).

Aquí se nota algo importante para la comprensión de las diferencias profundas entre la cultura occidental moderna y las que no son ni occidentales ni modernas, en este caso la indígena americana: el hombre nasa se comprende como un ente observador en relativa quietud en medio del tiempo/espacio que se mueve; la noción occidental en cambio parte de la idea del tiempo como una línea vectorial sobre la cual el hombre avanza 'hacia adelante', hacia el futuro. Según la concepción occidental hegemónica 'marchamos' hacia el futuro y por eso 'miramos' hacia el futuro - no parece importar el hecho de que en realidad no lo podemos 'ver'-, lo tenemos 'delante' mientras el 'pasado' (como indica su nombre en los idiomas europeos) ‘queda atrás' porque ya hemos 'pasado' por él. Esto demuestra que el valor simbólico-metafórico de las nociones y representaciones espaciales para la comprensión de la dinámica social humana en su dimensión temporal no es universal y difiere bastante en las diversas culturas. Este hecho tiene consecuencias para la visión del mundo, para su representación mental en la ciencia, la filosofía y las artes y - en consecuencia - para la manera de conceptualizar la historia. 
La cosmovisión de la Modernidad occidental, de cara al futuro, imagina la humanidad avanzando hacia él sobre una línea vectorial, con el pasado en la espalda. Esa es la idea del progreso tal como fue concebida desde la Ilustración e incluso antes, en los albores de la Edad Moderna. Esta cosmovisión está presente en muchos enfoques filosóficos y esta inmanente a la historiografía y las versiones canonizadas de la historia, ya que siempre son los vencedores los que la escriben. Benjamin adopta una actitud crítica ante este hecho. En sus Tesis de Filosofía de la Historia (1971), hace directamente la pregunta por el locus enuntiationis (“[...] ¿con quién compenetra el historiador historicista?”, 1971, pp. 80-81), y ése siempre implica un compromiso.

En la compleja, anti-sistemática, descentralizada y descomunal obra de Benjamin se trenzan y entretejen de manera original y productiva dos diferentes líneas de pensamiento, la una, mística y ajena al racionalismo ilustrado de la Modernidad occidental y la otra, basada en el materialismo histórico que constituye la más radical crítica del sistema social y político de la modernidad y sin embargo - al ser producto justamente de esa modernidad - lleva en sí, como la mónada, aquello que está criticando.

3. La alfombra del recuerdo. Acerca de un pensamiento descentralizado

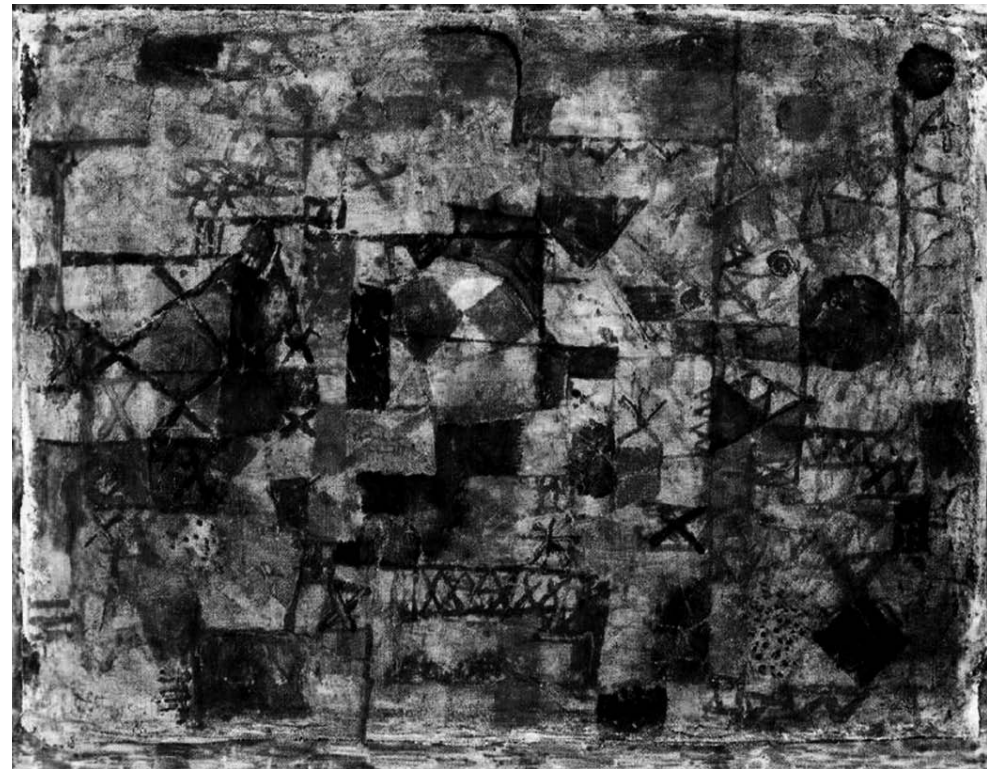

38. Paul Klee, La alfombra del recuerdo, 1914. Óleo sobre tela imprimada con tiza y óleo, sobre cartulina.

En 1014 Klee pintó La alfombra del recuerdo. Es una reminiscencia de su viaje al norte de África, a Túnez, y hace alusión a la tradición oriental magrebí de la tejeduría de kilims: una metáfora para la concatenación de los recuerdos que conforman la memoria. Un principio de la estética árabe es él de la infinitud (Puerta Vílchez, J.M. 1997); se expresa en los diseños textiles y arquitectónicos y las artes decorativas, por ejemplo en los arabescos y los diseños ad infinitum de los azulejos ornamentados que cubren paredes, pisos y cúpulas. 
El proyecto intelectual principal de Walter Benjamin a partir de 1927 ha sido la Obra de los Pasajes, el Passagen-Werk, según su título en alemán (1982a), que quedó inconclusa. Esa obra reviste gran importancia para la comprensión de los filamentos más intrínsecos y profundos del pensamiento de su autor, quien construye a la vez que visibiliza una coherencia e interrelación entre incontables ideas, episodios, documentos y citas que la conforman.

Pero, además, encierra claves para una crítica de las estructuras y dinámicas inmanentes en profundidad a la cultura occidental de la Edad Moderna. Esas claves pueden servir de punto de partida para encontrar nuevos modos, menos hegemónicos y centristas, de abordar los problemas culturales, estéticos e históricos dentro del actual contexto de la globalización. Benjamin sugiere con su obra un cambio epistemológico que hoy de hecho se está dando. Esta es la razón por la cual, después de haber sido un autor casi olvidado en las primeras décadas de la segunda posguerra, volvió a la palestra de los autores que revisten gran interés en el debate acerca de los paradigmas del conocimiento. La Obra de los Pasajes no es taxonómica; es un texto complejo y rizomático, está estructurado como un gran rizoma. En ese sentido - si bien probablemente esa no haya sido la intencionalidad consciente de Benjamin - el carácter inconcluso de la Obra de los Pasajes aparece como sintomático: los rizomas son infinitos. El largo texto, de 1350 páginas repartidas en dos gruesos tomos (1982a) - se compone de gran cantidad de elementos - muchos de ellos de carácter documental - interrelacionados sin jerarquización, en forma horizontal, sin centro o eje que los subordine, y que adquieren significado en su conjunto en cuanto mutuamente se revelan.

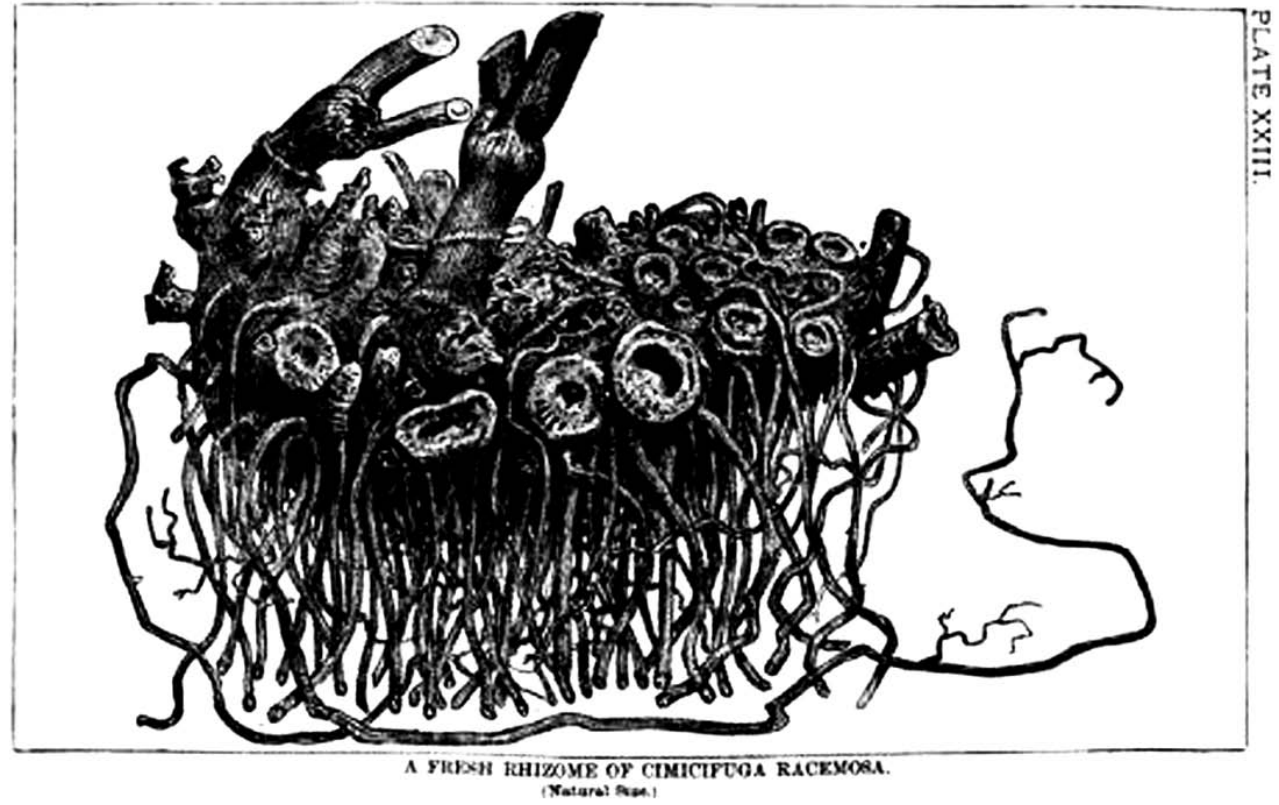

39. Rizoma de la planta cimifuga racemosa. Dibujo publicado en un libro de 1864, titulado Drugs and Medicines of North America, por Lloyd, J. U.\& Lloyd, C. G., Plate XXIII, p. 256. 


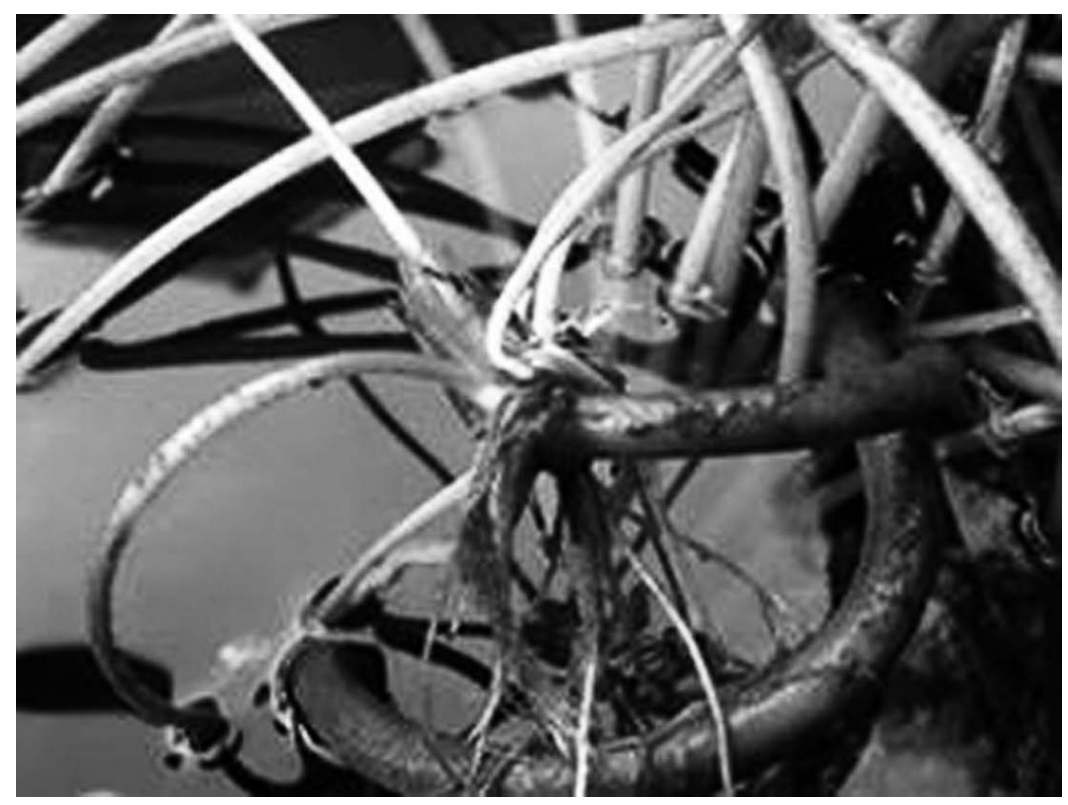

40. Rizoma de nenúfar. Fotografía de Daniel Flouret.

El término 'rizoma' es una metáfora derivada del mundo vegetal. Fue introducida por los filósofos Gilles Deleuze y Felix Guattari en la década los 70 (Deleuze y Guattari, 1977), para caracterizar una determinada forma de pensamiento, de estructuración del discurso, que es capaz de aprehender multiplicidades complejas. Benjamin no usó para ello la palabra 'rizoma' o 'rizomático', pero de hecho ya propuso esta forma de estructurar las ideas aplicándola en su Obra de Pasajes.

Para revelar la correspondencia entre las reflexiones filosóficas de Benjamin y las formas que adopta su pensamiento teórico - implícitamente proponiendo una nueva epistemología - es necesario tener en cuenta el contexto histórico, social, político y biográfico de la "Obra de los Pasajes".

Determinadas ideas filosóficas que tienen sus raíces en el misticismo talmúdico hebreo y el marxismo se juntan en el pensamiento de Benjamin en una amalgama muy original. En La Obra de los Pasajes estas dos vertientes iban a ser combinadas en un novedoso enfoque de la historia que arrojaría luz sobre el presente - un presente que para Benjamin era el de los años treinta del siglo XX, caracterizado por el avance de las fuerzas del fascismo y totalitarismo y, finalmente por el inicio de la Segunda Guerra Mundial.

El trasfondo y contexto de la Obra de los Pasajes es el cada vez más evidente fracaso del proyecto humanista de la Modernidad, que desemboca finalmente en un racismo agresivo legitimado en algunas partes como doctrina del Estado, el esclavismo masivo de los campos de trabajo forzado y de exterminio, el asesinato sistemático de millones de personas, no solamente en los países fascistas sino también bajo el régimen de Stalin. Ese trasfondo fue un elemento decisivo para el proceso de evolución de esta obra. 
Benjamin había publicado ya antes del exilio en forma más o menos dispersa gran parte de su multifacética producción ensayística. A partir de 1927 empezaba a tomar forma paulatinamente la idea del Passagen-Werk, que sería en adelante su obra principal, una empresa intelectual gigantesca en continuo devenir. El que la obra quedara interrumpida se debe evidentemente a las circunstancias difíciles que rodearon los últimos siete años de vida del autor: tuvo que abandonar finalmente el trabajo para salvar su vida - algo que no logró.

Pero también se debe a las enormes dificultades metodológicas que la obra - a raíz de su propia naturaleza - implicaba y que de hecho desborda de cierta manera la forma del libro como expresión tangible de la linealidad del tradicional del texto escrito.

El título de la Obra de los Pasajes- hace referencia a los Pasajes de Paris, construidas entre 1822 y 1835, un típico fenómeno de la incipiente Modernidad. Eran callejones con cubiertas de vidrio sostenidas por estructuras de hierro, que pasaban entre los edificios, entre los almacenes y tiendas, permitiendo al ciudadano deambular, entrar a cafés, ver las vitrinas y comprar. Fueron las primeras construcciones en hierro que jamás se han hecho - una en aquella época novedosa tecnología constructiva que luego, en la segunda mitad del siglo XIX habría de encontrar su pleno despliegue en numerosos puentes, en las cúpulas de los llamados jardines de invierno y jardines botánicos y la Torre Eiffel.

En el primer plan estructural para la Obra de los Pasajes, que data de 1927, Benjamin cita un texto, una "Guía ilustrada por Paris" del siglo XIX para visitantes foráneos:

Los Pasajes, un invento novedoso del lujo industrial, son callejones con cubierta de vidrio y enchapados en mármol que atraviesan la masa de edificios, cuyos propietarios se han unido para tal especulación. A ambos lados de estos callejones, que reciben su luz desde arriba, se alinean los almacenes más elegantes, así que un Pasaje de esos es una ciudad, un mundo en miniatura (citado según Benjamin, 1982 a, p. $45^{4}$; la traducción del alemán es mía).

41. Passage des Deux-soeurs. Ilustración de la edición alemana de la Obra de los pasajes (1998) de Benjamin, Foto de Germaine Krull

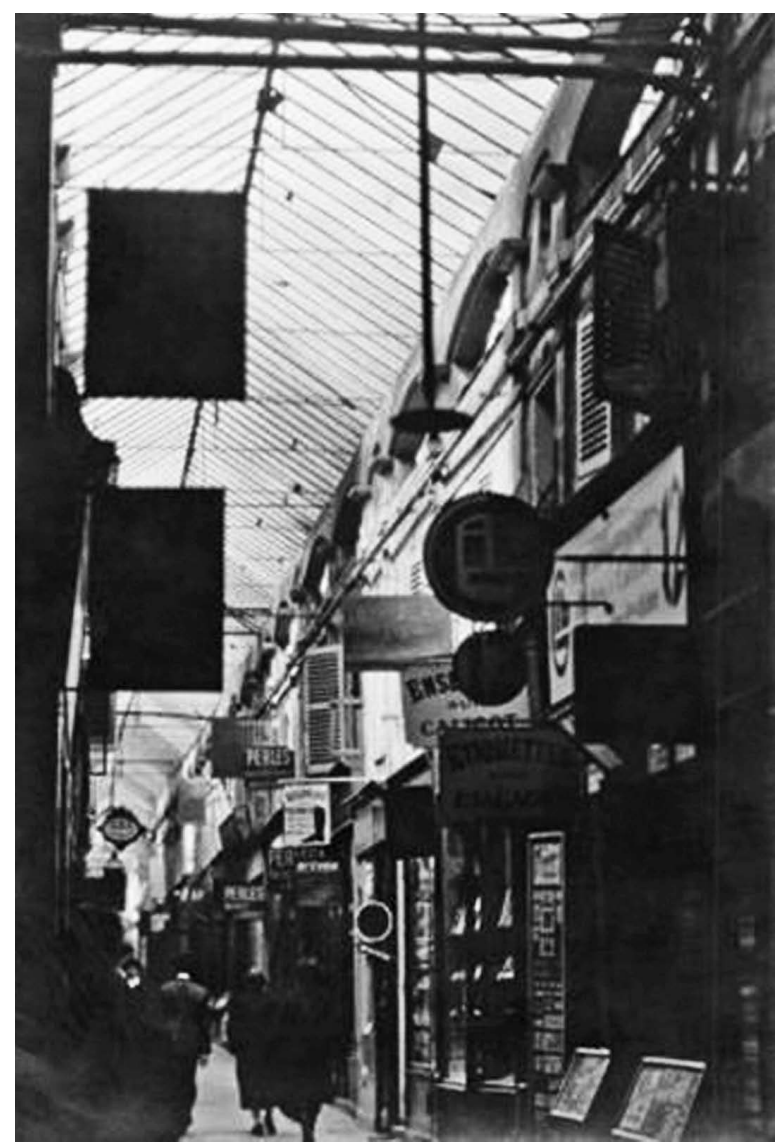




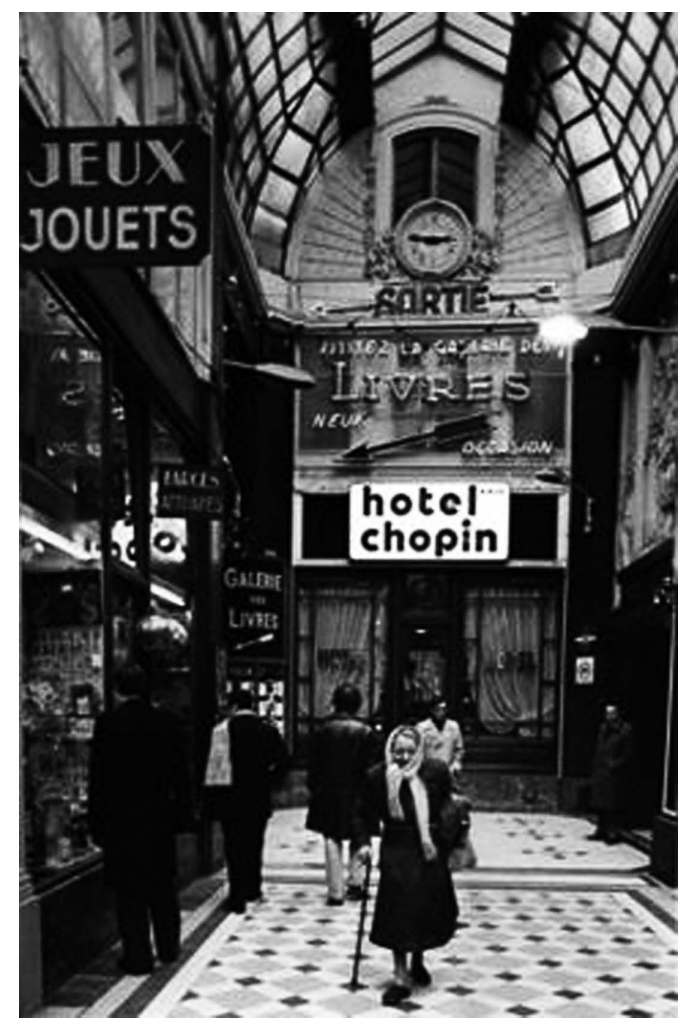

42. Passage Jouffroy - Hotel Chopin. Foto de Robert Doisneau, 1976

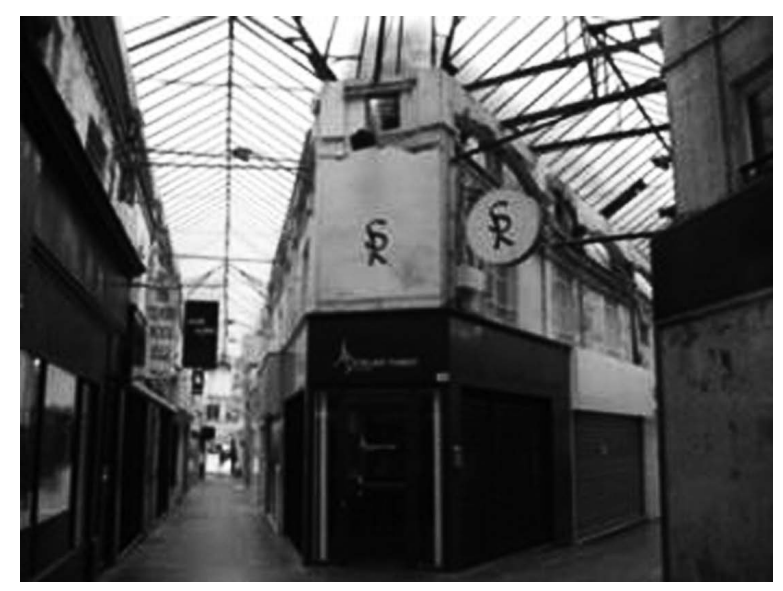

44. Passage du Caire

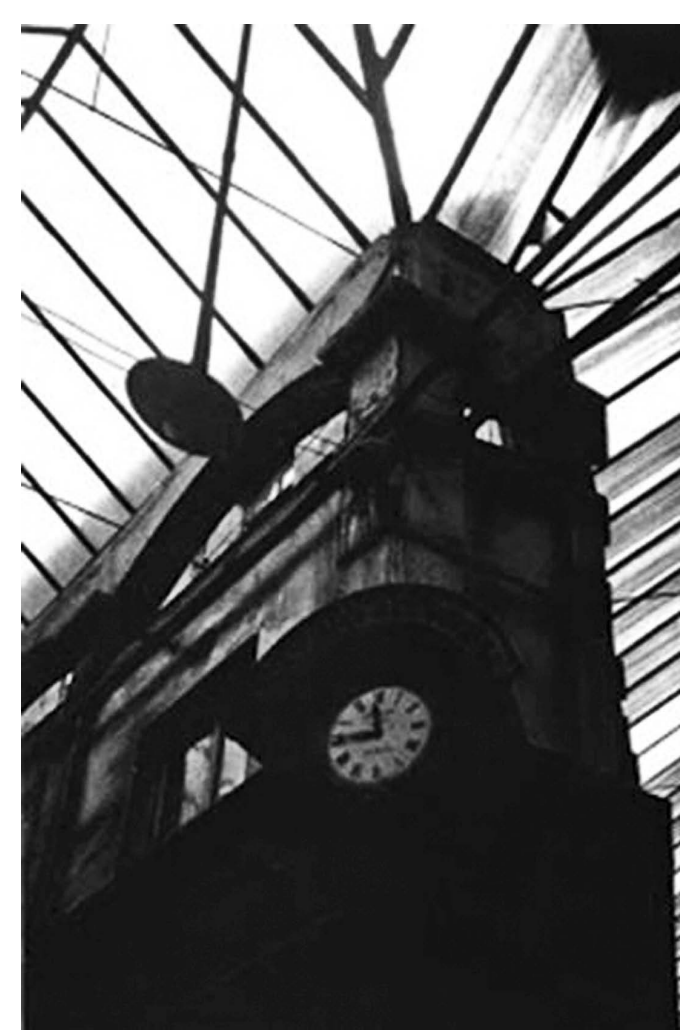

43. Passage du Caire (El Pasaje de Cairo), el más antiguo pasaje de Paris que data de 1798. Ilustración de la edición alemana de la Obra de los pasajes (1986) de Benjamin. Foto de Germaine Krull.

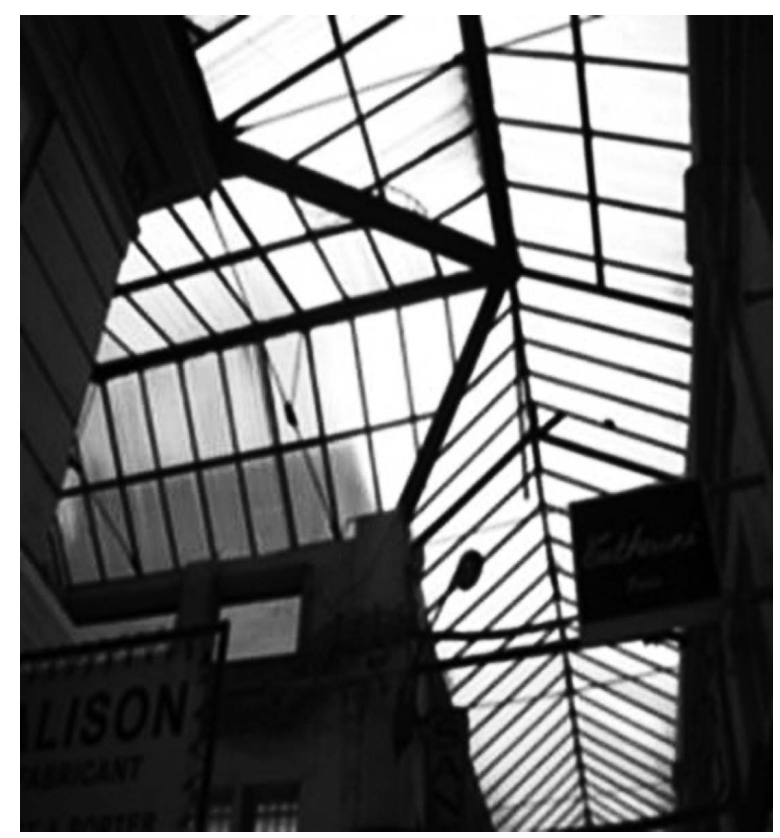

45. Passage du Caire. Techos acristalados. 
Según la idea de Benjamin, los Pasajes fueron un punto clave en la configuración del concepto moderno de ciudad y por ende de la Modernidad misma, ya que ella está inseparablemente vinculada al despliegue de la cultura urbana. Por ello los Pasajes de París constituyeron para Benjamin una especie de quinta esencia de la modernidad capitalista, cuya expresión es la metrópoli, la gran ciudad como cúmulo rizomático de un modo de vida basado en el consumo y la movilidad.

Con La Obra de los Pasajes Benjamín pretendía algo completamente novedoso: quería realizar una historia y/o filosofía de la materialidad del siglo XIX, o sea, del siglo por excelencia de la Modernidad, del siglo del triunfo del capitalismo, una historia que no partiera de un concepto abstracto central sino de los hechos particulares y concretos.

Si bien Benjamín no concluyó este monumental proyecto, hay una serie de obras que de él se desprendieron y surgieron a partir de él: El autor como productor, publicado en 1934, Paris, la capital del siglo XIX, publicado en 1935, La obra de arte en la época de su reproductibilidad técnica, publicado en 1935-36, Algunos motivos de Baudelaire, publicado en 1937-39, El narrador, publicado en 1937-39, Eduard Fuchs - el coleccionista e historiador, publicado en 1937-39.

La más conocida entre ellas, La obra de arte en la época de su reproductibilidad técnica (Benjamin, 1973) está dedicada a problemas relacionados con el siglo XX pero se encuentra estrechamente conectada con el proyecto de la Obra de los Pasajes: constituye su lugar de referencia, su locus enuntiationis. Es un análisis de aspectos y fenómenos significativos correspondientes al lugar histórico desde el cual la mirada de Benjamin - y con ella la del lector - se dirige hacia el pasado.

Por ello proporciona la clave para la memoria, el recuerdo, que desentraña lo sucedido con beneficio del presente.

Es justamente el significado de la famosa alegoría del Angelus Novus, el ángel de la historia al que Benjamin se refiere en 1940, en su última obra, las Tesis de filosofía de la historia.

El material mismo de la Obra de Pasajes consiste en miles de observaciones, citas, notas, anécdotas y documentos que Benjamin reunió minuciosamente en fichas para formar con ellos un mosaico de lo concreto, de lo particular, como un enorme rizoma, un tejido horizontal de urdimbre y trama, - una alfombra del recuerdo - que excluye la lectura lineal, ya que la narración lineal implica un punto de vista hegemónico.

Así el siglo XIX iba emergiendo en su materialidad, en su carácter anecdótico y concreto, como lo hace emerger la memoria: ... Solo en la imagen, que relampaguea de una vez para siempre en el instante de su cognoscibilidad, se deja fijar el pasado, con el fin de su apropiación espiritual para el presente (Benjamin, 1971, p.79). 


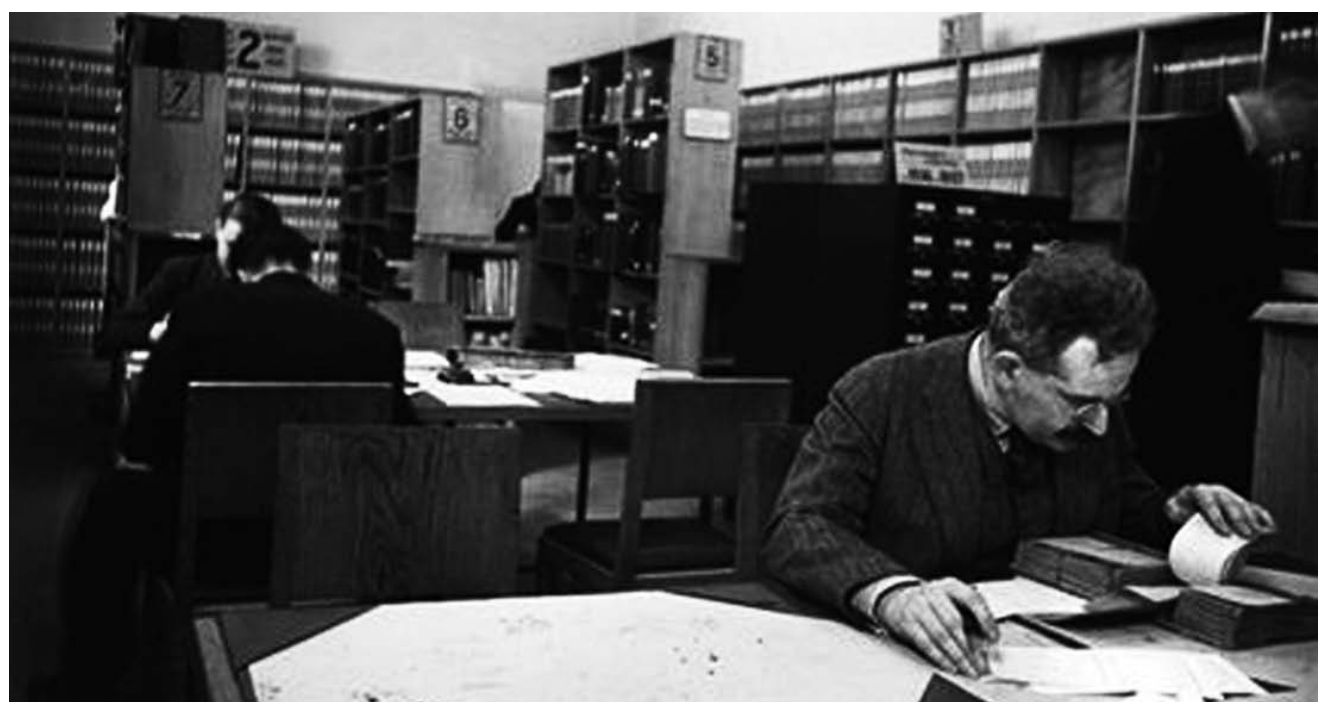

46. Benjamin, en la Biblioteca Nacional de París, inclinado sobre sus fichas para la Obra de los Pasajes. Ese método permitiría estructurar variablemente el texto resultante, algo que la escritura lineal en cuadernos no permitía. Hoy la escritura en computador facilita esa movilidad de párrafos e ideas. Foto tomada alrededor de 1939-40.

La idea de la mónada jugó un papel importante:

Benjamin consideraba que los detalles, los acontecimientos, objetos tangibles, las anécdotas, todas las formas contienen la esencia de la totalidad, que en cada detalle particular está contenido el todo y hay que hacerlo visible. Allí aparece la idea derivada de la filosofía de Leibniz y de las investigaciones naturalistas de Goethe, la de la planta originaria, del protozoo, de la mónada en la que está contenida, aunque sea en estado latente, la totalidad.

Salta a la vista la coincidencia con la idea estética de Klee, expresada en 1920, ya citada arriba (Klee, 15 marzo 2010, párrafo 7), respecto a la sustancialización que se presenta en el arte nuevo. Benjamin se había propuesto logar esa substancialización en lo concreto de los miles de fragmentos de memoria. Para ello le debía servir el principio del montaje: un principio de composición. Ese principio ya había sido experimentado y explorado anteriormente en el arte vanguardista: en el cubismo con su de-construcción y re-construcción de las formas bajo diferentes puntos de enfoque (loci enuntiationis), mediante el collage y el fotomontaje, mediante el cine y sus nuevas posibilidades tecnológicas e igualmente en la literatura.

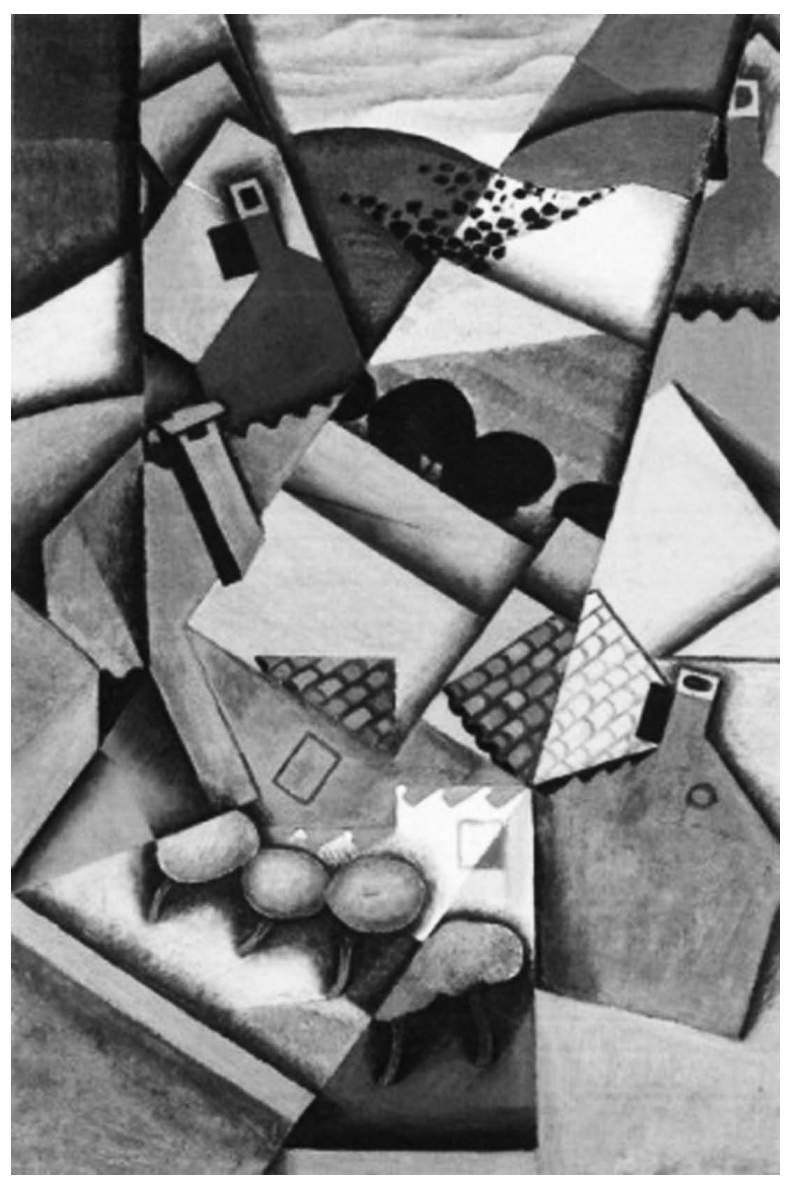

47. Juan Gris, Paisaje con casas en Ceret, 1913 


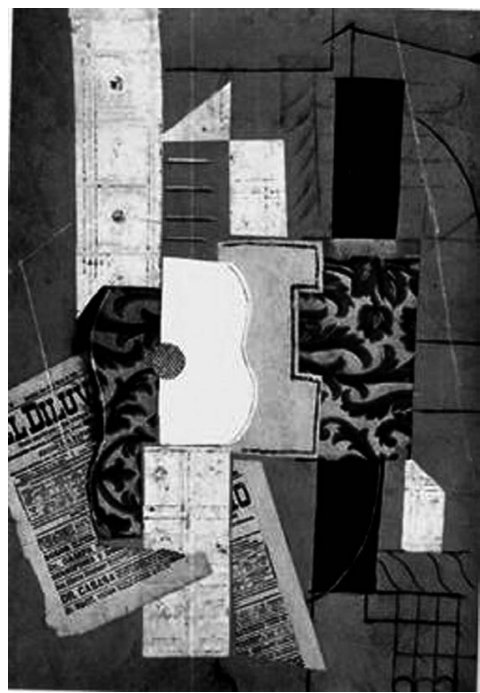

48. Picasso, Violín, collage cubista, 1913

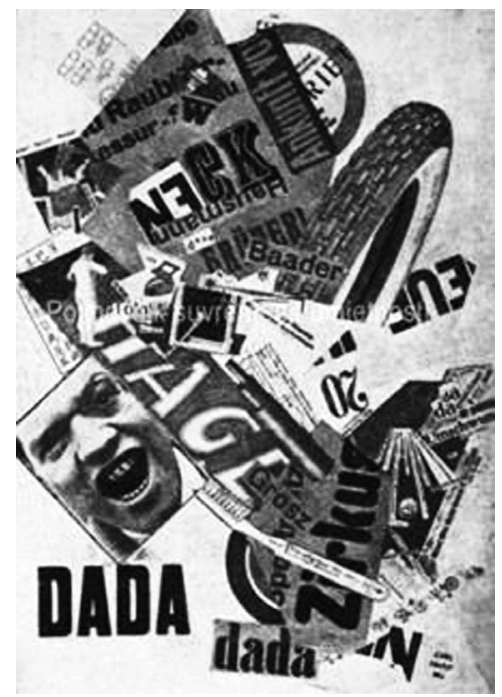

49. George Grosz \&John Heartfild, País soleado. Collage/fotomontaje dadaísta, 1923

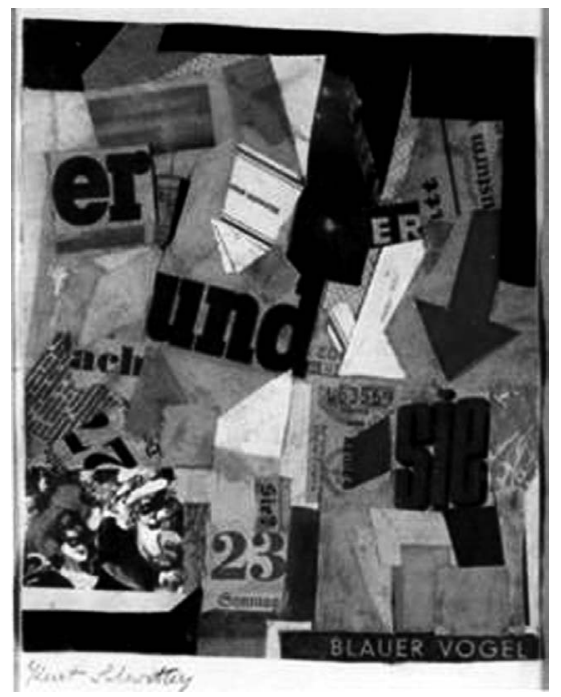

50. Kurt Schwitters, Pájaro azul, collage, dadaísta, 1922

Es interesante el paralelo con la novela Manhattan Transfer de John Dos Passos (Dos Passos, 1984), que data de 1925: debe suponerse que se trata de una coincidencia, aunque es posible que Benjamin haya conocido la novela. Como sea: la coincidencia es sintomática porque se deriva de un propósito semejante: Manhattan Transfer se llamaba en aquella época una estación del Subway, un nodo de líneas del metro de Nueva York (que existe desde 1904). 'Manhattan Transfer' es para Dos Pasos una metáfora en doble sentido: para los flujos y la movilidad de la Metrópoli moderna de la que trata su novela y para la novedosa estructura de montaje literario que usó.

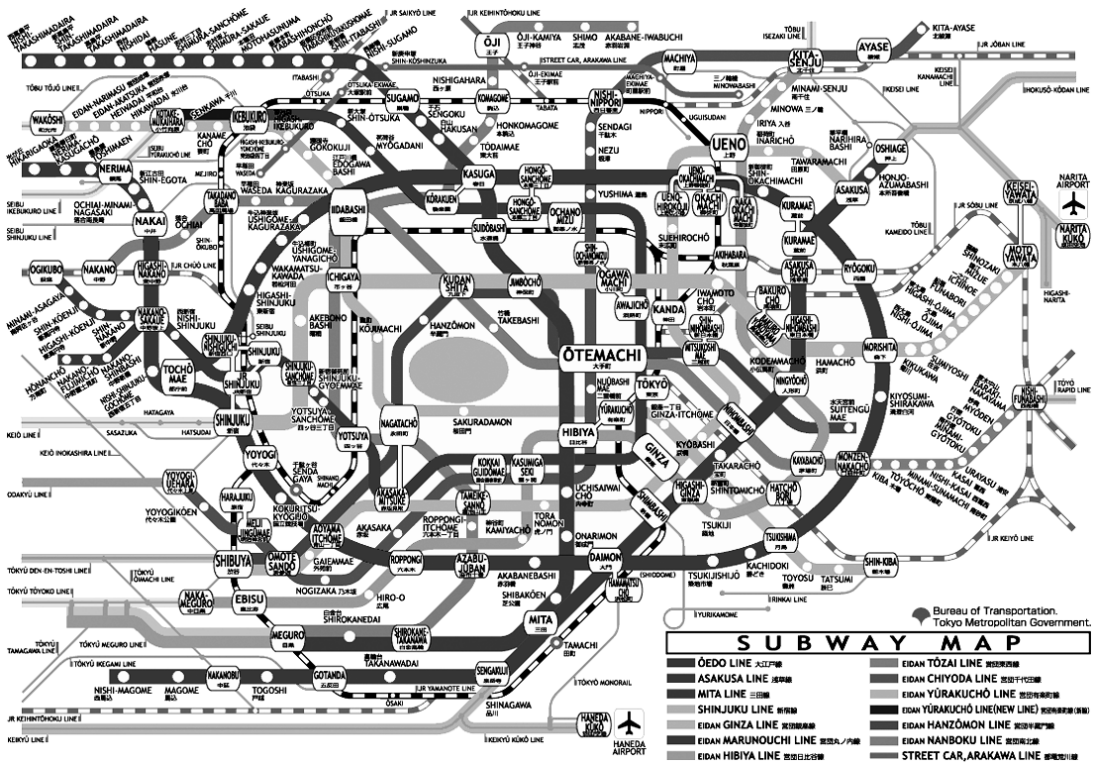

51. El Subway de Tokio, mapa para la orientación urbana 


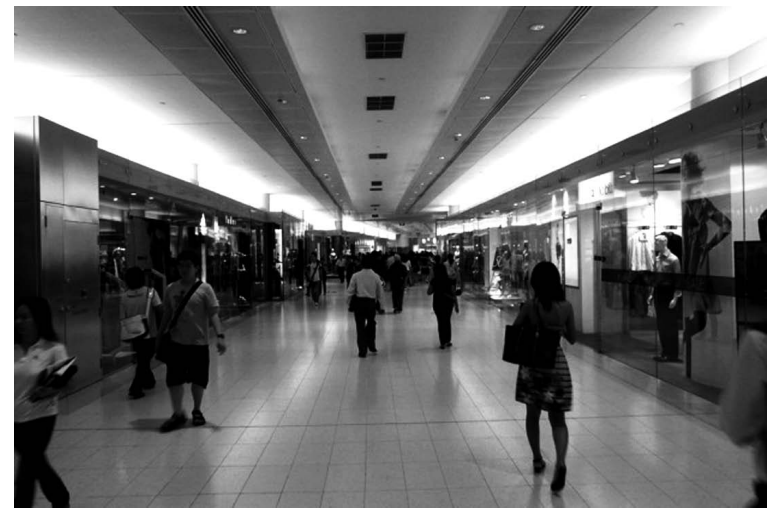

52. Estación del metro en Singapur actualmente

53. Los Pasajes de Paris, construidos a comienzos del siglo XIX, hoy restaurados

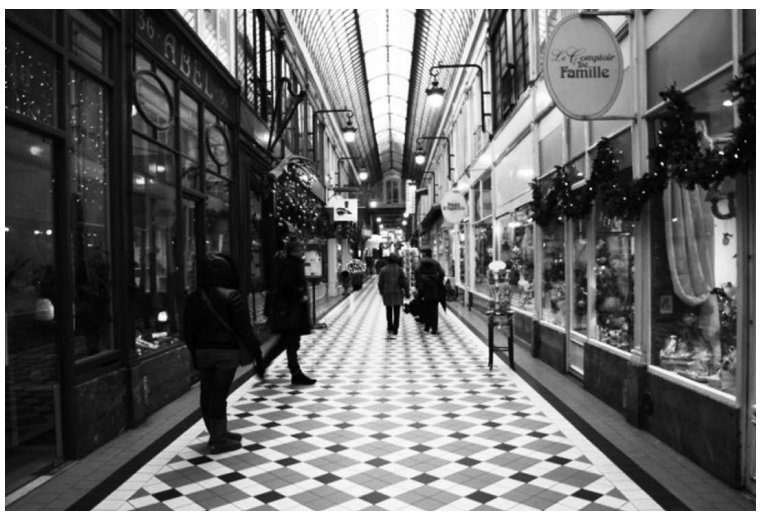

Para Benjamín los Pasajes de Paris, a comienzos del siglo XIX, entrañan la esencia y dinámica de la gran ciudad moderna y a la vez el tejido que estructura su Obra de los Pasajes, trama y urdimbre de las interconexiones del pensamiento, 'el rizoma de la memoria'.

Benjamin realizó una apropiación epistemológica profunda de ese principio que va más allá de una simple metodología. Para él tenía plena validez el principio estético tan importante para la comprensión del arte de vanguardia: la unidad de forma y contenido, no la correspondencia entre forma y contenido, que postula la estética tradicional de occidente, donde la forma sigue al contenido, sino la afirmación más profunda que equipara forma y contenido: la forma es contenido y contenido siempre es forma.

La separación teórica entre forma y contenido - anclada en toda la concepción occidental del arte desde el Renacimiento, basado en la representación - es y sigue siendo uno de los principales obstáculos para la comprensión de la índole del arte de las vanguardias y la problemática del arte hasta nuestros días. Solamente una profunda aprehensión del principio fundamental de la unidad entre forma y contenido, posibilita esta comprensión, lo que implica un giro conceptual copernicano.

Lo interesante es que Benjamin, consecuente con sus ideas y en correspondencia con los enfoques del arte de vanguardia (del que como teórico y escritor participaba) adopta ese teorema filosóficamente, algo que transforma su praxis teórica. La manera tradicional de escribir la historia, con su uni-focalidad y narración lineal conlleva una postura discursiva que implica la perspectiva desde el poder; por lo tanto, hace imposible visualizar aquellos elementos del pasado cuyo conocimiento es necesario para transformar el presente. ¿Con quién - pregunta Benjamin en las Tesis de filosofía de la historia - se compenetra el historiador historicista?, (Benjamin, 1991), y contesta: 
La respuesta suena inevitable: con el vencedor. Pero los amos

eventuales son los herederos de todo aquello que han vencido. Por

consiguiente, la compenetración con el vencedor resulta cada vez más

ventajosa para el amo del momento....Quien quiera haya conducido la

victoria hasta el día de hoy, participa en el cortejo triunfal en el cual los

dominadores de hoy pasan sobre aquellos que hoy yacen en tierra....

Por lo tanto, el materialista histórico se distancia en la medida de lo

posible. Considera que su misión es la de pasar por la historia el cepillo

a contrapelo (Benjamin, 1971, p.81).

La memoria permite "pasar por la historia el cepillo a contrapelo" (Benjamin, 1971, p.81), permite acceder a estos elementos del pasado cuyo conocimiento es necesario para transformar el presente; la memoria no es lineal ni unifocal. La memoria constituye un complejo rizoma, cuya recuperación requiere del montaje, de una nueva forma, una estructura descentralizada, pluri-focal y compleja.

Benjamin también quería establecer una nueva constelación entre el material y la teoría, entre la cita y la interpretación, una nueva manera de exégesis, una nueva hermenéutica. El peso se iba a trasladar hacia el lado de la cita, hacia el material concreto, hacia el documento. Interpretación y teoría explícita deberían permanecer latentes, deberían fungir como meros principios de organización en el montaje, evitando de ese modo al máximo la discursividad hegemónica.

La idea era realizar el montaje de tal forma que la esencia de la totalidad fuera visible en el más pequeño elemento de construcción como refractada en un cristal. De esta manera la historia ya no quedaría desplegada diacrónicamente a lo largo de la cronología del tiempo occidental sino condensada en una infinidad de instantáneas, como en un caleidoscopio en el que en miles de instantes relampaguea la totalidad en su esencia.

Para asimilar una obra de esta naturaleza se requiere también de un nuevo lector, capacitado para leer y comprender no solamente un texto sino también - y sobre todo - capacitado para descifrar la realidad misma por debajo de su epidermis, capacitado para leer consciente- y críticamente los hechos de la vida, leer los fenómenos visuales y auditivos, táctiles, gustativos y olfativos, un lector dotado del nuevo sensorium que se formaría - según Benjamin - bajo el impacto y en consecuencia de los efectos de la tecnología nueva, un lector equipado con aquella capacidad crítico-analítica que Brecht apreciaba y trataba de potenciar en los espectadores-participantes de su teatro.

La Obra de los Pasajes es un voluminoso material de miles de fichas, densamente cubiertas con apuntes, citas, notas y referencias en la letra manuscrita de Benjamin. La publicación de este material inconcluso era una empresa editorial muy complicada que solo pudo realizarse en 1989. ¿Cómo pensaba Benjamin articular y estructurar estos apuntes, citas, notas y referencias? No es fácil saberlo, ya que el material mismo no lo revela. Pero se sabe, por los diferentes planos estructurales que se conservaron que 
Benjamin no tenía en mente un orden narrativo lineal con una secuencia fija, sino una red de complejas interconexiones cruzadas. ${ }^{5}$

De hecho una obra de esa naturaleza y envergadura era técnicamente casi imposible de realizar mediante los recursos de la época, que eran aun esencialmente la escritura en papel y el formato del libro. El libro, que corresponde físicamente a un orden de ideas lineal, es - por lo menos en su forma impresa - un producto de la modernidad. La oralidad - medio tradicional para la memoria - no implica necesariamente esa linealidad - y tampoco los soportes electrónicos digitales actuales la implican.

Las dificultades que Benjamin debió haber enfrentado en cuanto a la estructuración de su Obra de Pasajes en forma de libro deben haber sido enormes. Hoy, mediante el computador y los nuevos sistemas tecnológicos es posible superar el discurso lineal y se puede pensar en textos en forma de un tejido de interconexiones bidimensionales, tridimensionales e incluso multi-dimensionales en cuanto a su estructura semántica, textos que constituyen una red de referencialidad compleja.

Benjamin se preguntaba ¿hasta qué punto es posible ser concreto en una problemática de filosofía de la historia? En la descripción de calles, alamedas, panoramas, exposiciones mundiales, moda, publicidad, prostitución, el coleccionista, el vendedor ambulante, el fotógrafo, el recolector de deshechos, el jugador, las luchas desde las barricadas durante la Comuna de Paris, las redes ferroviarias, la bolsa, el caricaturista Daumier, Marx, Fourier, Saint Simon, el tedio, el rió Sena, la fascinación por lo oriental, los espectáculos panorámicos, las litografías y en general las técnicas de reproducción impresa, las construcciones en hierro, el iluminado público, la vida literaria, la literatura de los folletines, el kitsch, el hacinamiento en los inquilinatos, la organización del trabajo asalariado... en todo ello y más en su conjugación encuentra Benjamin la esencia del capitalismo y de la Modernidad. Una de sus características es la rapidez exponencial del envejecimiento y la caducidad casi inmediata de las novedades, inventos tecnológicos y de la información, algo que se encuentra en relación directa con el despliegue de las fuerzas productivas del sistema capitalista. ${ }^{6}$

Benjamin quería hacer visible la impronta del sistema en sus desechos, en sus residuos físicos y mentales, en la memoria, mediante un montaje, una composición. Esto mismo también se hizo en el arte ya en la década de los años 20. Se evidencia, por ejemplo, en las obras del dadaísta Kurt Schwitters.

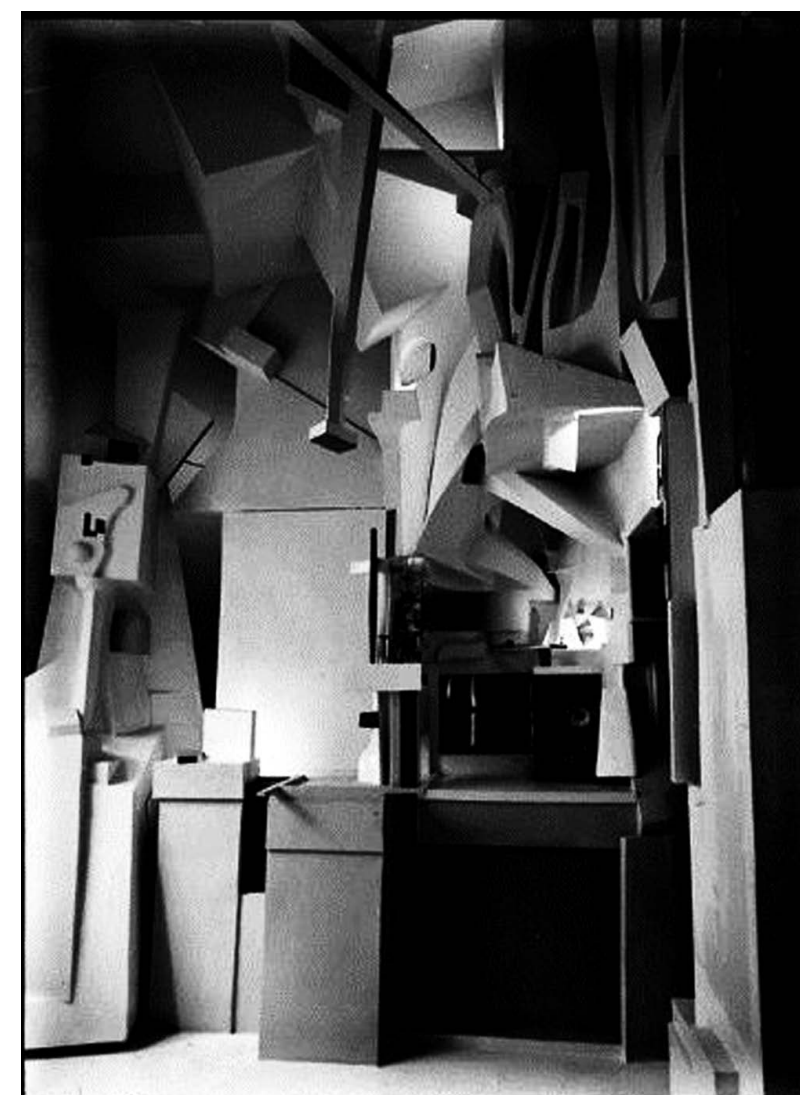

54. Dadaísmo: Kurt Schwitters, Merzbau, 1932 ensamblaje de objetos de deshecho Foto de la reconstrucción de la obra: Kurt Schwitters Archive, Sprengel Museum Hanover 


\section{Posdata}

La variabilidad, pluralidad y relatividad del locus enuntiationis y las formas rizomáticas de concatenación de ideas, particularmente en los procesos de memoria, son tan antiguas como la humanidad misma. Están presentes en las manifestaciones estéticomitológicas africanas, por ejemplo en la escultura de máscaras e ídolos mágicoreligiosos que inspiraron las formas del Cubismo y del Expresionismo de comienzos del siglo XX, y en las narraciones poético-musicales de los aedas africanos, los griots. Están presentes en el pensamiento oriental de tradición árabe y en el judaísmo que tan fuertemente marcaron durante los siglos medievales (y de hecho hasta hoy) la cultura intelectual y estética en la Península Ibérica y que por otro lado inspiraron las ideas de Benjamin y Klee. Están presentes en la cultura medieval cristiana europea en general ya que las raíces del cristianismo son orientales. Están presentes en las manifestaciones pictóricas, escultóricas y mitológicas de los pueblos originarios de América de cuya riqueza actualmente solo conocemos la punta de un iceberg que amenaza con derretirse si no se contrarresta pronto ese proceso reconociendo plenamente la importancia que ese legado reviste para toda la humanidad. Están presentes por todo ello de múltiples maneras en las formas ideológicas y estéticas sincréticas populares de Nuestra América desde la época colonial, y están presentes también en las tradiciones y formas de construir pensamiento mediante la imagen, el sonido, el movimiento corporal, el diseño de objetos y entornos físico-tangibles y el lenguaje de muchos otros pueblos de Asia, Australia y Oceanía.

Desde la Europa de la Edad Moderna con sus dos columnas sostenedoras económico-ideológicas, ambas objetivantes, el coloniaje extractivo y la hegemonía del saber tecnocientífico instrumental, se impuso en las manifestaciones pictóricas y discursivas el predominio de la perspectiva central, la pretensión de un punto de vista único, objetivante y pretendidamente omnisciente y la linealidad deductiva y teleológica del vector unidireccional del tiempo histórico como progreso.

55. El mito del viaje al inframundo. Reproducción graficada de una pictografía azteca. Detalle.

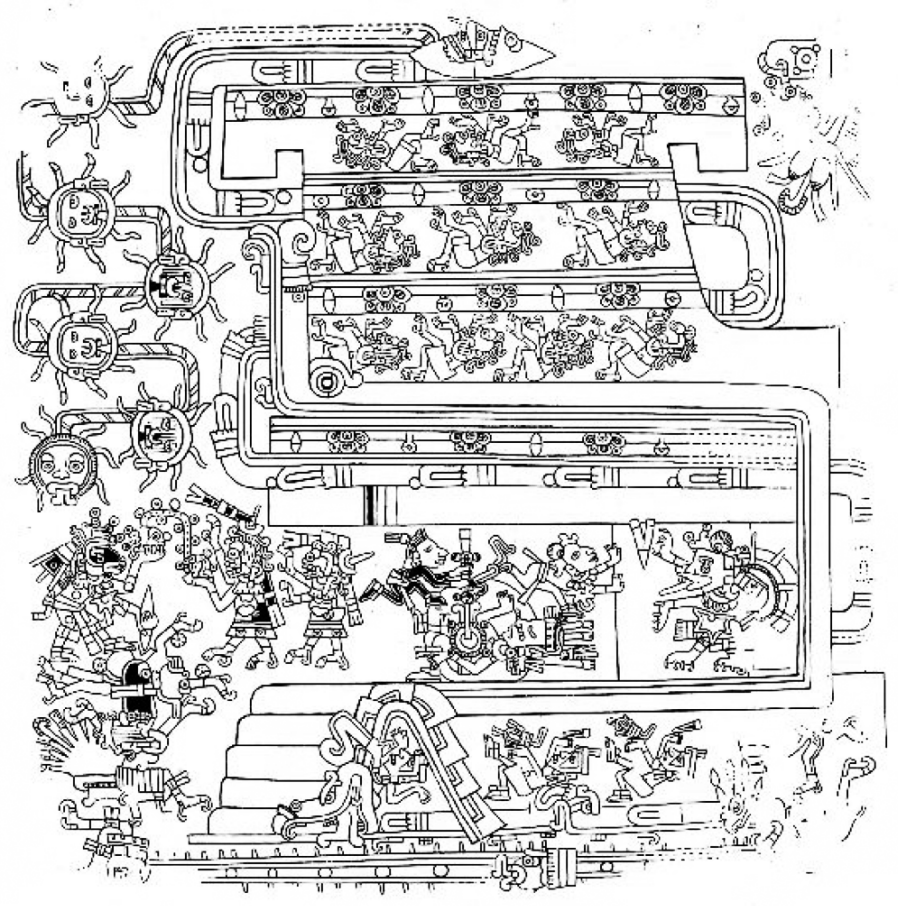



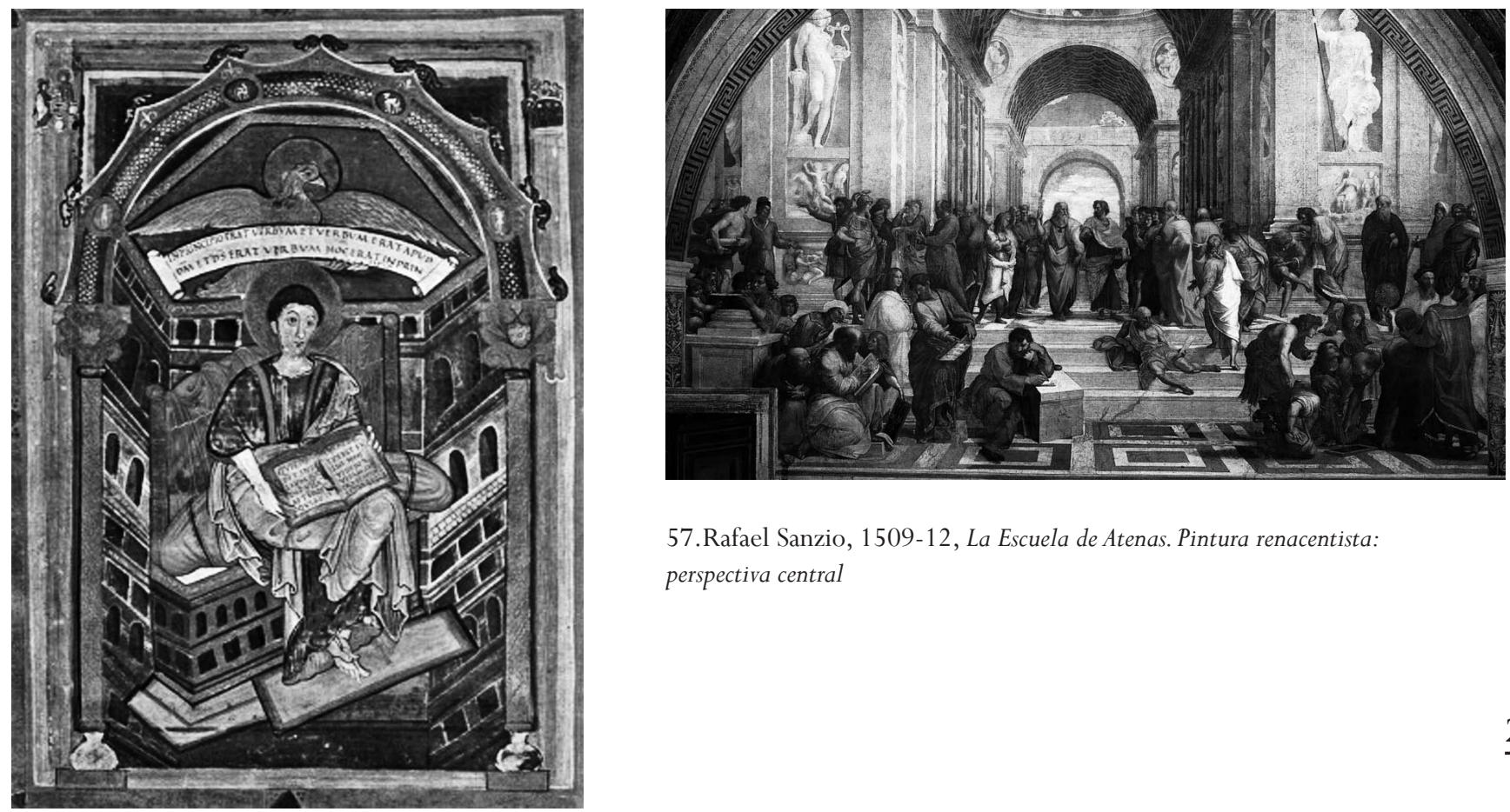

57.Rafael Sanzio, 1509-12, La Escuela de Atenas. Pintura renacentista: perspectiva central

56. Anónimo, comienzos del siglo X, Evangeliario de San Medardo - San Juan. Pintura medieval con perspectiva múltiple

Eso se relaciona con lo que Lyotard (1994) ha llamado "grandes relatos" y cuya deconstrucción se ha iniciado, particularmente en los enfoques más esclarecidos e innovadores de las ciencias humanas, los llamados nuevos paradigmas epistemológicos (Fried Schnitman ed., 1994; Denzin y Lincoln, 2005; Denzin, Lincoln y Smith, 2008) que apenas empiezan a tener primeros, y aún tímidos efectos también sobre las ciencias naturales, todavía llamadas “duras” en aras justamente de su rigidez epistemológica. Las vanguardias artísticas, con su apertura hacia los avances tecnológicos exponenciales de los siglos XX y XXI por un lado y por el otro hacia las culturas arcaicas y tradicionales de los pueblos originarios de muchas partes del mundo, abrieron brecha en ese sentido (como muestra el ejemplo de Klee), y fueron seguidos luego por algunos filósofos y pensadores teóricos (como muestra el ejemplo de Benjamin). Ellos fueron pioneros de un gran cambio de paradigma que se está iniciando contra viento y marea, en contravía de los tradicionales paradigmas estéticos y científicos de la Modernidad Occidental, articulados sistémicamente con el principio económico de la generación de plusvalía a ultranza. Ese nuevo paradigma apunta hacia formas de-coloniales de pensar y conceptualizar, y por lo tanto de organizar, el mundo.

Walter Benjamin pasó los últimos años de su vida en la Biblioteca Nacional de Paris, tejiendo su alfombra de la memoria del siglo XIX, juntando una ficha tras otra, reuniendo dato tras dato, pero reflexionando sobre un angustiante presente: el fascismo se había apoderado de varios países europeos, había triunfado contra los republicanos en la 
Guerra Civil Española, se expandió desde Alemania a Austria, Checoslovaquia y más allá, anexando territorios al 'Tercer Reich' de Hitler; una segunda Guerra mundial y la invasión a Francia estaban inminentes.

Pero eso no era todo: en la Unión Soviética, que durante los años veinte había sido el punto de fuga de las esperanzas sociales y políticas de muchos intelectuales demócratas, el régimen de Stalin perseguía, acusaba y condenaba al destierro, a trabajos forzados o a la muerte muchos revolucionarios de primera hora, entre ellos artistas de vanguardia. Asja Lacis, quien había introducido a Benjamin al marxismo fue detenida y desterrada a Kazajstán en Asia central- no sabemos si Benjamin alcanzó a enterarse de esto. Stalin firmó un pacto de no agresión con Hitler y si bien eso no era sino una treta política de él para ganar tiempo y dilatar el ataque alemán a la Unión Soviética, ese hecho debe haber sido doloroso y desesperanzador para los opositores antifascistas en occidente.

Paul Klee estaba en Suiza. Aunque allí estaba a salvo de persecuciones directas, los acontecimientos geo-políticos lo angustiaron a tal grado que entró en una profunda depresión. Se enfermó gravemente y solo pudo volver a trabajar artísticamente por un corto tiempo después de 1937. Sus obras de aquella época hablan por él.

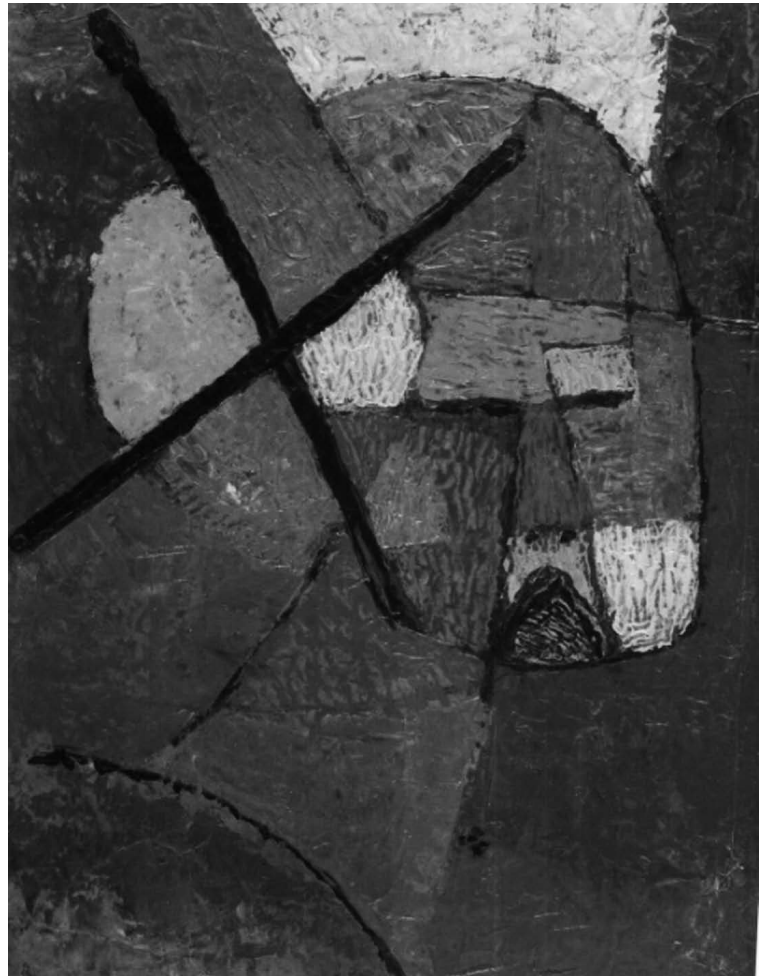

58. Klee, Borrado de la lista, 1933. Colores al óleo sobre papel encerado transparente

59. Klee, Danzas cansadas por el miedo, 1938. Acuarela negar sobre papel ingres sobre cartulina.

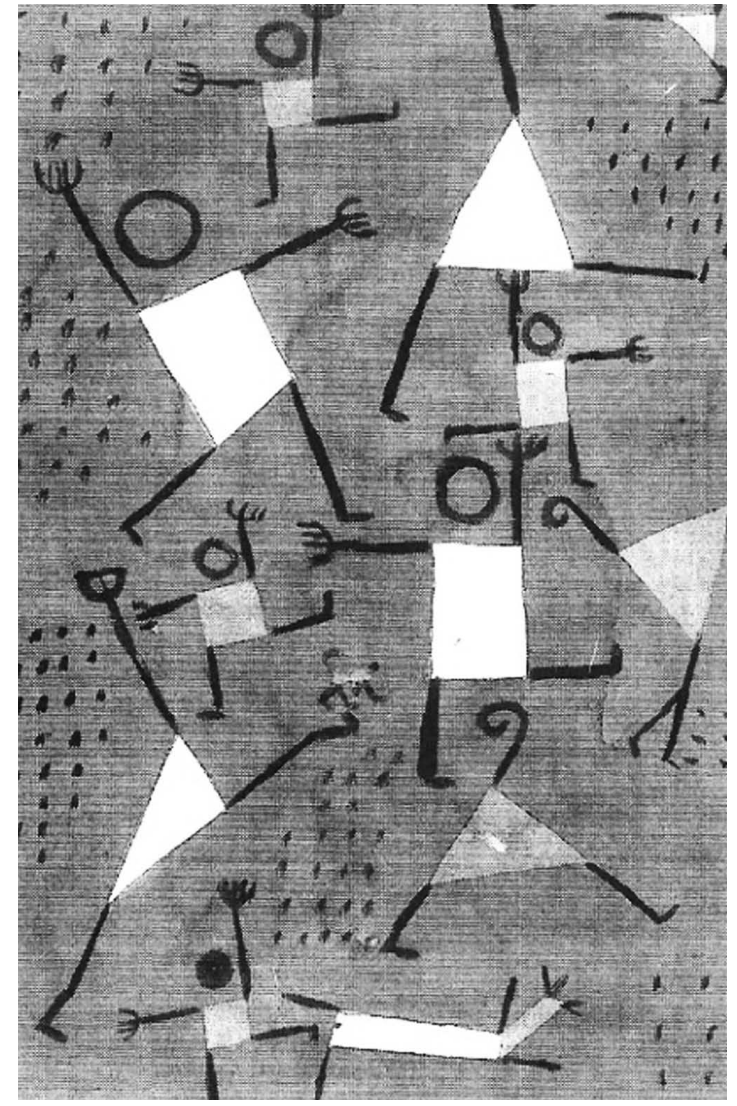




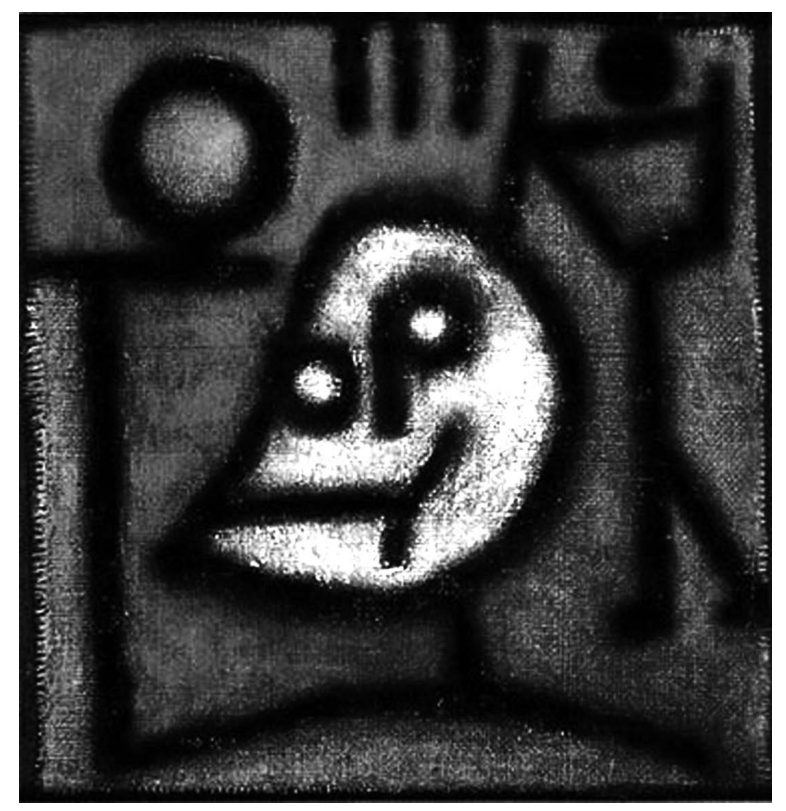

60. Klee, Muerte y fuego. 1934, Tempera sobre arpillera. Boca y ojos del rostro semi-abstracto que aparece en el cuadro forman la palabra 'Tod', que significa 'muerte' en alemán.

61. Klee, Arrebato de miedo II, 1939, acuarela sobre papel ingres sobre cartulina.

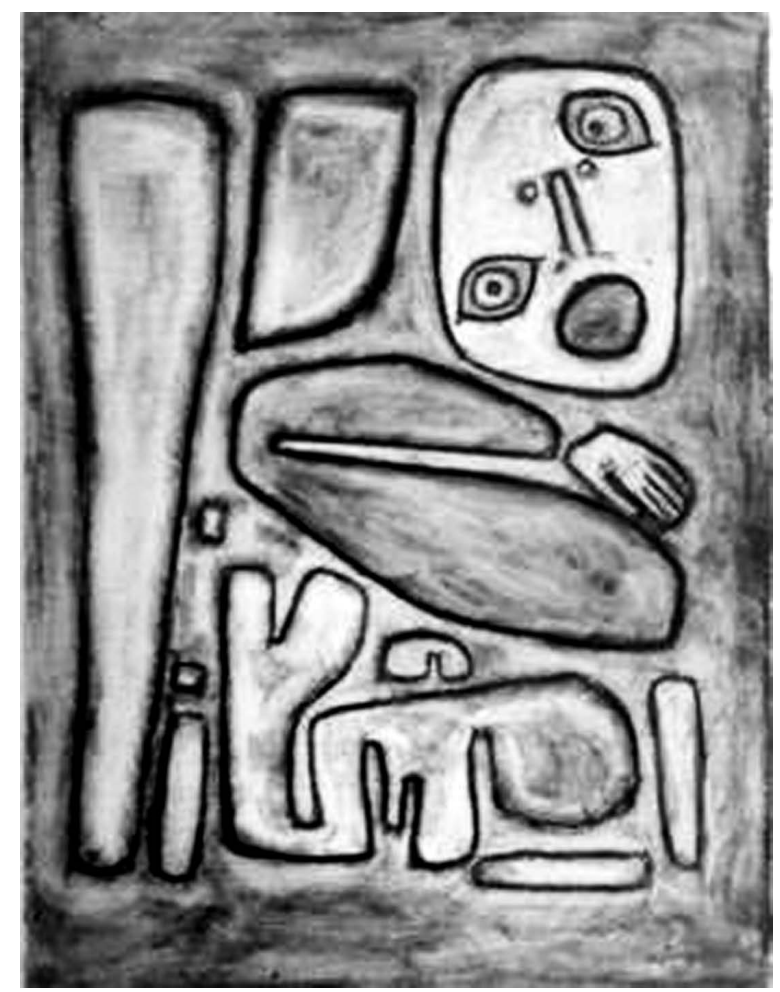

Ambos, Klee y Benjamin, murieron en 1940. El trasfondo de sus muertes era el mayor infierno que la humanidad había visto en toda su historia, llevado a cabo con la tecnología más avanzada y genial que mente humana jamás había inventado. La razón guía y principio fundamental de la civilización occidental moderna - se había eclipsado a sí misma.

Pero lo que Klee y Benjamin legaron, sus nuevas formas de pensar visual o filosóficamente parece presagiar un cambio, un cambio que ellos intentaron iniciar cada uno a su manera, pero que de hecho durante los oscuros años que les tocó vivir no estaba al alcance de la mano. El interés y la asimilación que sus ideas - particularmente las de Benjamin - encuentran hoy y las repercusiones que tienen para una mejor comprensión de lo que acontece en ese mundo del que hacemos parte, indican que en medio de la violencia y las luchas sin cuartel en muchas partes se está dando un paulatino cambio. 


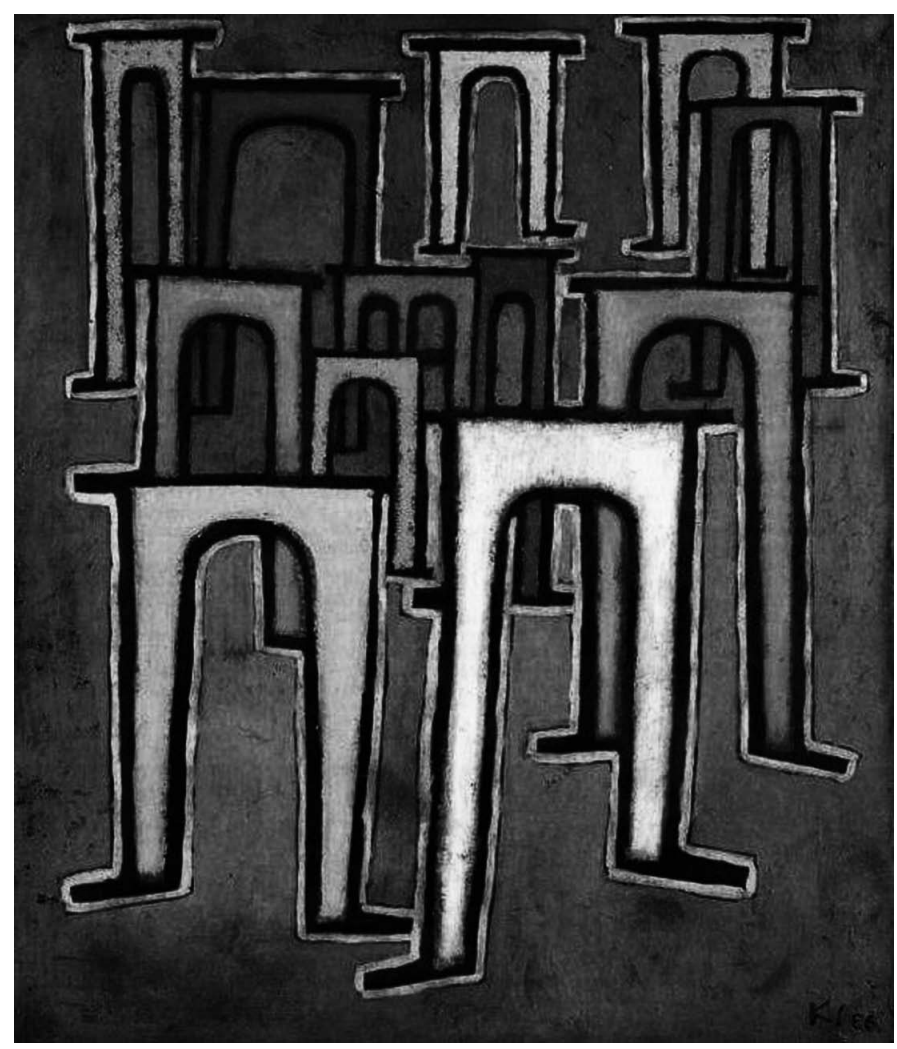

62. Klee, Revolución del viaducto, 1939, óleo sobre lienzo

Las rígidas estructuras, como las columnas portantes del Viaducto de Klee (imagen 62), están saliendo de quicio, rompen filas, abandonan el orden establecido: algo nuevo se pone en camino.

\section{Notas}

${ }^{1}$ Título de la investigación matriz del texto: Las teorizaciones postcoloniales y el pensamiento latinoamericano. Implicaciones para arte y estética: Pensadores en contravía. Matrices decoloniales en Benjamin. Bataille, Brecht y Bajtin.

2 Profesora titular de la Universidad del Valle. Fundadora del Departamento de Artes Visuales y Estética y cofundadora de la Facultad de Artes Integradas, de la que ha sido Decana. También ha sido años profesora del Instituto Departamental de Bellas Artes y de la Universidad Santiago de Cali, donde fue directora de la revista Grafos. Es alemana y reside desde 1976 en Colombia.

${ }^{3}$ El antropólogo y profesor de la Universidad del Valle de Cali, Víctor Daniel Bonilla, comunicó esta observación en una ponencia como participante en una mesa redonda sobre cultura latinoamericana, celebrada en el salón del Consejo Municipal de Cali, en 1988.

3 "Die Passagen, eine neuere Erfindung des industriellen Luxus, sind glasgedeckte, marmorgetäfelte Gänge durch ganze Häusermassen, deren Besitzer sich zu solchen Spekulationen vereinigt haben. Zu beiden Seiten dieser Gänge, die ihr Licht von oben erhalten, laufen die elegantesten Warenläden hin, so dass eine solche Passage eine Stadt, ja eineWelt im kleinen ist."(Benjamin, 1989, o. 45)

${ }^{5}$ Julio Cortazar trató más tarde, en 1963, de lograr algo similar en su novela Rayuela (1979).

${ }^{6}$ Hector Lavoe, uno de los más geniales cantantes de salsa - música urbana por excelencia - condensó eso en su canción Periódico de ayer que trata de un amor pasajero, “desechable”, pero, más allá de eso, capta, tanto en la música como en la letra, ese espíritu urbano moderno. 


\section{Referencias}

Bajtin, M. M, (1986) Problemas de la poética de Dostoievski. México,D.F., Fondo de Cultura Económica

Bambula Díaz, J. (1993) Lo estético en la dinámica de las culturas. Cali, Universidad del Valle

(2014) Artes y conocimiento. Particularidades de la investigación/ creación/producción en el campo estético, en: revista $A$ contratiempo, $\mathrm{N}^{\circ} 23$, Ministerio de Cultura de Colombia, disponible en: http:/ / acontratiempo. bibliotecanacional.gov.co/

Benjamin, W. (1963) Städtebilder. Frankfurt am Main, Suhrkamp Verlag . (1969) Über Literatur. Frankfurt am Main, Suhrkamp Verlag .(1969) Über Kinder, Jugend und Erziehung. Frankfurt am Main, Suhrkamp

Verlag .(1970) Lesezeichen. Leipzig, Reclam Verlag .(1971) Angelus Novus. Barcelona, Editorial Sur

.(1971) Das Paris des Second Empire bei Baudelaire. Berlin und Weimar,

Aufbau-Verlag .(1972) Versuche úber Brecht. Frankfurt am Main, Suhrkamp Verlag . (1972) Vom Ursprung des deutschen Trauerspiels. Frankfurt am Main,

Suhrkamp Verlag . (1973) La obra de arte en la época de su reproductibilidad técnica. Madrid, Editorial Taurus. . (1974) Charles Baudelaire. Frankfurt am Main, Suhrkamp Verlag . (1982a) Gesammelte Schriften, BandV-1 y V-2, Das Pasagen-Werk. Frankfurt am

Main, Suhrkamp Verlag

. (1982b) Infancia en Berlín 1900. Madrid, Ediciones Alfaguara

.(1987) Dirección única. Madrid, Editorial Alfaguara

. (1995) Haschisch. Madrid, Santillana S.A. (Taurus)

. (1998) Imaginación y sociedad. Madrid, Editorial Taurus

. (2010) Über den Begriff der Geschichte. Disponible en: http://www.

mxks.de/files/phil/Benjamin.GeschichtsThesen.html, 15 de abril 2016

Brecht, B. (1977) Arbeitsjournal 1938-1955. Berlin, Aufbau-Verlag

Colombo, M. Paul Klee en fragmentos (15 marzo 2010) Blog del amasijo. El blog de coto. Párrafo 7. Recuperado el 15 de abril 2014 de: http: / / blogdelamasijo.blogspot. com.co/2010/03/paul-klee-en-fragmentos.html

Cortazar, J. (1979) Rayuela. Bracelona, Editorial Bruguera S.A.

Danzel, T.W. (1922) Mexico I. Bilderhandschriften. Hagen i.W. und Darmstadt, FolkwangVerlag G.m.b.H..,

Deleuze, G. y Guattari, F.(1977) Anti-Ödipus. Kapitalismus und Schizophenie. Frankfurt am Main, Suhrkamp Verlag

Denzin, N.y Lincoln, Y. eds. (2005). The Sage Handbook of Qualitative Research-Third Edition. Thousand Oaks, London, New Delhi: Sage Publications 
Denzin, N.; Lincoln, Y. y Smith, L.T., eds. (2008). Handbook of Critical and Indigenous Methologies. Los Angeles: Sage Publications.

Dos Passos, J. (1984) Manhattan Transfer. Bogotá, Editorial Seix Barral,S.A.

Fried Schnitman, D. ed., 1994. Nuevos paradigmas, cultura y subjetividad. Buenos Aires, Barcelona, México: Editorial Paidós

Hobsbawm, E. (2011) Cómo cambiar el mundo. Barcelona, Crítica S.L.

Horkheimer, M. (1967) Zur Kritik der instrumentellenVernunft, Frankfurt am Main, S.Fischer Verlag (2002) Crítica de la razón instrumental. Madrid, Editorial Trotta

Horkheimer, M. y Adorno, T. W. (1969), Dialektik der Aufklärung. Frankfurt am Main, S. Fischer Verlag GmbH,

. (1994) Dialectica de la Ilustración. Madrid, Editorial Trotta,

1994;

Huntington, S.P. (1996) Kampf der Kulturen. Die Neugestaltung der Weltpolitik im 21.

Jahrhundert. Wien - München, Europaverlag

. (2004) Who AreWe. The Challenges to America's National Identity. New York,

London, Toronto, Sydney, Simon \& Schuster

Joyce, J, (1976) Ulysses. Harmondsworth-Middlesex, Penguin Books

Laszlo, Ervin, 1989, La gran bifurcación. Crisis y oportunidad: anticipación del nuevo paradigma que está tomando forma. Editorial Gedisa, Barcelona

Lorenz, Konrad, 1973, Die acht Todsünden der zivilisierten Menschheit, Piper Verlag, München;

Lukácas. G. (1968) Frühschriften II. Geschichte und Klassenbewusstsein. Darmstadt und

Neuwied, Hermann Luchterhand Verlag G,bH \& Co KG

Lyotard, J. F. (1994): La condición posmoderna, Madrid: Editorial Cátedra

Partsch, S. (1991), Paul Klee - 1879-1940. Köln, Verlag Benedikt-Taschen

Puerta Vilchez, J.M. (1997) Historia del pensamiento estético árabe. Madrid, Ediciones

Akal,S.A.

Sloterdijk, P. (1983) Kritik der zynischen Vernunft. Frankfurt am main, Suhrkamp Verlag

Sarrazin, T. (2010) Deutschland schafft sich ab.Wie wir unser Land aufs Spiel setzen. München, Deutsche Verlagsanstalt

\section{Referencias de las imágenes}

1. Paul Klee, Angelus Novus, 1920. Dibujo a tinta china, tiza y acuarela sobre papel. Museo de Israel, Jerusalén

2. Paul Klee, pintor, 1879-1940. Recuperada el 10 de abril 2016 de: http:/ / tasswira.canalblog. com/archives/2007/09/14/6206509.html

3. Walter Benjamin, filósofo, 1892-1940. Recuperada el 10 de abril 2016 de: http:// walterbenjaminportbou.cat/en/content/walter-benjamin

4. La última foto de Paul Klee, tomada el día 20 de febrero 1940. Recuperada el 12 de abril 2016 de: http://www.svreumatologia.com/paul-klee/

5. Gershom Scholem. Recuperado el 12 de abril 2016 de: https://es.pinterest.com/ $\mathrm{pin} / 555772410242670274 /$

6. Asja Lacis . Recuperado el 12 de abril 2016 de: http://www.gramscimania.info.ve/2012/04/ un-raro-amor-de-walter-benjamin.html

7. Ernst Bloch. . Recuperado el 15 de abril 2016 de: http: / www.auswanderung-rlp.de/ emigration-in-der-ns-zeit/ernst-bloch.html 
8. Georg Lukács. Recuperado el 15 de abril 2016 de: http://www.rosa-blindada.info/?p=2641

9. Bertolt Brecht. Recuperado el 15 de abril 2016 de: https: / / es.pinterest.com/ pin/480196378989948097/

10. Foto del pasaporte alemán de Walter Benjamin. Recuperado el 15 de abril 2016 de: https:// kmarx.wordpress.com/2014/07/24/el-marxismo-romantico-de-walter-benjamin/

11. Última foto de Benjamin, 1940, reseña policial en Port Bou. Recuperado el 15 de abril 2016 de: http: / / revistadeletras.net/el-walter-benjamin-de-la-obra-de-arte-en-la-epoca-de-sureproducibilidad-tecnica/

12. Representación de la Urpflanze, según las ideas de Goethe; xilografía de Pierre Jean François Turpin, 1837. Recuperado el 15 de abril 2016 de: https: / / commons.wikimedia.org/wiki/ File:Urpflanze.png

13. Klee, 1930, Tiene cabeza, mano, pie y corazón. Acuarela y pluma sobre algodón, sobre cartulina sobre placa de aglomerado. Recuperado el 15 de abril 2016 de: http:/ /www.allpaintings. org/v/Expressionism/Paul+Klee/Paul+Klee+-+Tiene+cabeza_+mano_+ jpg.html

14. Klee, Vista de Kairuan, 1914, acuarela. Recuperado el 15 de abril 2016 de: http: / / de.wahooart.com/@@/8LT4A4-Paul-Klee-Ansicht-von-Kairouan

15. Klee, Domos rojos y blancos. Acuarela, 1914. Recuperado el 18 de junio 2016 de: http:/ /www. percepolegatto.com.br/2012/11/06/ja-viu-o-predio-onde-ela-mora/

16. Klee, Arquitectura, 1923. Recuperado el 15 de abril 2016 de: https://de.pinterest.com/ $\operatorname{pin} / 538109855447052792 /$

17. Klee, Armonía de cuadriláteros, 1923. Recuperado el 15 de abril 2016 de: http: / / es. wahooart. com/@@/8LT45B-Paul-Klee-armon\%C3\%ADa-de-\%60squares\%60-en-rojo,-amarillo,azul,-blanco-y-negro

18. Klee, La muerte por la idea, 1915, litografía a la pluma. Recuperado el 15 de abril 2016 de: http: / / www.wikiart.org/es/paul-klee

19. Klee, Destrucción y esperanza, 1916, litografía y acuarela. Recuperado el 15 de abril 2016 de: http: / / www.mutualart.com/Artwork/Zerstorung-und-Hoffnung/4D634807151C0587

20. Klee, El Káiser Guillermo maldiciendo, 1920, pluma. Recuperado el 15 de abril 2016 de: http:/ / forums. civfanatics.com/showthread.php?p=13831653

21. Represión contra los revolucionarios de la República de Consejos Muniquesa A. fotos históricos de 1919. Recuperado el 15 de abril 2016 de: https: / www.historisches-lexikonbayerns.de/Lexikon/Rote_Armee,_1919

22. Klee, Pájaros tirándose en picada, 1919, técnica mixta. Recuperado el 15 de abril 2016 de: https: / / misiglo.wordpress.com/tag/paul-klee/

23. Klee, El héroe con el ala, 1905, aguafuerte, Recuperado el 15 de abril 2016 de: http: / / arteaula23.blogspot.com.co/2013/05/paul-klee-1879-1940.html 29.

24. 1917, avión alemán sobrevolando las Pirámides de Guiza, imagen captada desde otro avión. Foto histórica. Recuperado el 15 de abril 2016 de: http:/ / www.lexikon-erster-weltkrieg.de/ Luftstreitkr\%C3\%A4fte

25. Avión alemán volando sobre Inglaterra durante la Primera Guerra Mundial. Foto histórica, captada desde otro avión. Recuperado el 20 de abril 2016 de: http: / vchistorica.blogspot. com.co/2013/10/la-aviacion-durante-la-primera-guerra.html

26. 1915: El piloto de caza Max Immelmann, 'héroe' de la Primera Guerra Mundial, fue llamado El Águila de Lille por su habilidad para realizar maniobras en picada en los ataques aéreos contra Francia. Foto histórica. Recuperado el 15 de abril 2016 de: http:/ /www. librosmaravillosos.com/lahistoriadelaaviacion/capitulo03.html

27. En 1916 solo quedaron los restos de su avión. Foto histórica. Recuperado el 15 de abril 2016 de: http: / / lapausadelcafe.es/home/los-ases-y-sus-aviones/el-fokker-e-1-de-max-immelmann. html

28. Klee, El mito de la flor, 1918, acuarela sobre indiana imprimada de tiza sobre papel periódico sobre cartulina, ribeteado de purpurina. Recuperado el 28 d mayo 2016 de: http: / / www. allpaintings.org/v/Expressionism/Paul+Klee/Paul+Klee+-+Mito+de+la+flor.jpg.html 
29. Klee, Pájaro cayendo, 1918, colores al agua y tinta de impresión sobre papel, ribeteado con tinta, monada sobre cartón. Recuperado el 15 de abril 2016 de: https://www.google.com.co/ search?q $=$ Klee $+\mathrm{P} \% \mathrm{C} 3 \% \mathrm{~A} 1$ jaro ${ }_{\text {cayendo } \& \mathrm{espv}}=2 \& \mathrm{biw}=1366 \& \mathrm{bih}=663 \& \mathrm{tbm}=\mathrm{isch} \& \mathrm{tbo}=\mathrm{u}$ \&source $=$ univ\&sa $=$ X\&ved=0ahUKEwiTl_q89pTMAhUMGB4KHbd3D4UQsAQIGQ\#tbm=i sch\&q $=$ Klee + Falling + Bird\&imgrc $=$ tduDbiLthWOQOM $\% 3 \mathrm{~A}$

30. Klee, Con el águila, 1918, colores al agua sobre base roja sobre papel ingres imprimado con tiza, con soporte de papel satinado verde sobre cartulina. Recuperado el 15 de abril 2016 de: https: / / es.pinterest.com/pin/470204017325789472/

31. Klee, Separación vespertina, 1922, acuarela. Recuperado el 18 de abril 2016 de: https: / / jmrcjmrc.wordpress.com/2013/05/06/2013-05-04-3-madrid-paul-klee-y-pompeya/

32. Klee, Lugar afectado, 1922, acuarela, dibujo a pluma con tinta china sobre lápiz, sobre papel sobre cartulina. Recuperado el 15 de abril 2016 de: https:/ / es.pinterest.com/ $\mathrm{pin} / 529665606145754763 /$

33. Klee, Caminos principales y caminos laterales, 1929, óleo sobre tela. Recuperado el 15 de abril 2016 de: https: / /xgfk13pcbr.wordpress.com/m5/ Klee, Curioso a la manera vegetal, 1929, colores al agua sobre acuarela sobre papel imprimado de negro sobre papel acuarelado sobre cartulina. Recuperado el 15 de abril 2016 de: http: / /www.paintingmania.com/curioso-lamanera-vegetal-115_19916.html

34. Klee, Curioso a la manera vegetal, 1929, colores al agua sobre acuarela sobre papel imprimado de negro sobre papel acuarelado sobre cartulina. Recuperado el 15 de abril 2016 de: http:/ / www.paintingmania.com/curioso-la-manera-vegetal-115_19916.html

35. Mirada por el microscopio: La semilla de la flor delfín. Autora: Masoumeh "Sahar” Khodaverdi. Universidad de Tabriz, Tabriz, Irán. Estuvo entre las 10 ganadoras del concurso internacional de fotografía digital "Olympus Bioscape"2012. The image was acquired from multiple Z-stacked images. Recuperada el 16 de abril de: http: / /www.24horas.cl/noticiasbbc/en-fotos-lasmaravillas-del-mundo-microscopico-469103

36. Klee, Flora en el peñasco, 1940, óleo sobre temple sobre yute. Recuperado el 15 de abril 2016 de: http:/ / www.wikiart.org/en/paul-klee/flora-on-rocks-sun-1940

37. El helecho-musgo selaginella denticulata tapizando una roca, fotografía publicada por Juan Bibiloni en su blog Sangrando en verde, el 9 de diciembre de 2010. Recuperado el 18 de mayo 2016 de: http:/ /jardin-mundani.blogspot.com.co/2010/12/selaginella-denticulata-elhelecho_09.html

38. Paul Klee, La alfombra del recuerdo, 1914, óleo sobre tela imprimada con tiza y óleo, sobre cartulina. Recuperado el 15 de abril 2016 de: https: / / es.pinterest.com/ $\mathrm{pin} / 326511041704358660 /$

39. Rizoma de la planta cimifuga racemosa. Dibujo publicado en el libro de 1864, Drugs and Medicines of North America por Lloyd, J. U.\& Lloyd, C. G. , Plate XXIII, p. 256. Recuperado el 19 de abril 2016 de: http://www.henriettes-herb.com/eclectic/dmna/pics/dmna-pl-23. html

40. Rizoma de nenúfar. Fotografía de Daniel Flouret. Recuperado el 19de abril 2016 de: http:/ / www.elestanque.com/plantas/fichas_nenufares_templados/nenufar_mexicana_rizoma.html

41. Passage des Deux-soeurs. Ilustración de la edición alemana de la Obra de los pasajes (1998) de Benjamin, Foto de Germaine Krull Recuperado el 18 de mayo 2016 de: http: / / bosquetriangular.blogspot.com.co/2011/12/pasaje-des-deux-soeurs-paris.html

42. Passage Jouffroy - Hotel Chopin. Foto de Robert Doisneau, 1976. Recuperado el 15 de abril 2016 de: http: / /www.tedkinsey.com/ug-blog/

43. Passage du Caire (El Pasaje de Cairo), el más antiguo pasaje de Paris que data de 1798. Ilustración de la edición alemana de la Obra de los pasajes (1986) de Benjamin. Foto de Germaine Krull. Recuperado el 19 de mayo 2016 en: https: / /bookofsmall.wordpress. com/\#jp-carousel-522

44. Passage du Caire. Recuperado el 19 de mayo 2016 de: https: / bookofsmall.wordpress. com/\#jp-carousel-525

45. Passage du Caire. Techos acristalados. Recuperado el 15 de mayo 2016 de: https: / /bookofsmall. wordpress.com/2013/06/11/passageducaire/passageduccaire-05/ 
46. Benjamin, en la Biblioteca Nacional de París, inclinado sobre sus fichas para la Obra de los Pasajes. Ese método permitiría estructurar variablemente el texto resultante, algo que la escritura lineal en cuadernos no permitía. Hoy la escritura en computador facilita esa movilidad de párrafos e ideas. Foto tomada alrededor de 1939-40. Recuperado el 15 de abril 2016 de: http:/ / salonkritik.net/10-11/30493pqK.jpg

47. Juan Gris, Paisaje con casas en Ceret, 1913. Recuperado el 15 de abril 2016 de: http: / / algargosarte.blogspot.com.co/2014/10/juan-gris-pintor-del-cubismo-sintetico.html

48. Picasso, La guitarra, collage cubista, 1913. Recuperado el 15 de abril 2016 de: http: / / admalexandrawand.blogspot.com.co/2011/05/analisis-la-guitarra-collage-pablo.html

49. George Grosz \&John Heartfield jun. País soleado. Collage, 1922. Recuperado el 15 de abril 2016 de: http: / / www.thelightingmind.com/los-manifiestos-dada/

50. Schwitters, Pájaro azul, 1923. Recuperado el 15 de abril 2016 de: 1922. Recuperado el 15 de abril 2016 de: http: / / maiadezan.net78.net/wp-content/uploads/2013/01/Kurt-SchwittersBlue-Bird-1922.jpg/

51. El Subway de Tokio, mapa para la orientación urbana. Recuperado el 15 de abril 2016 de: https: / / es.pinterest.com/pin/92816442290011174/

52. Estación del metro en Singapur hoy. Recuperado el 15 de abril 2016 de: https: / /www. google.com $\cdot \mathrm{co} /$ search? $q=$ Metro + Singapur\&espv $=2 \& b i w=1366 \& b i h=663 \&$ source $=\operatorname{lnms} \& \mathrm{t}$ $\mathrm{bm}=$ isch\&sa $=$ X\&ved=0ahUKEwjt7-O3vpLMAhUDJR4KHWlxAWwQ_AUIBigB\#imgrc $=$ 2sKhDLZJMfm8M\%3A

53. Los Pasajes de Paris, hoy, construidos a comienzos del siglo XIX. Recuperado el 15 de abril 2016 de: https: / / radinito.wordpress.com/2010/12/25/navidad-en-paris/

54. Dadaísmo: Kurt Schwitters, Merzbau, 1932 ensamblaje de objetos de deshecho. Photo (repro): Kurt Schwitters Archive, Sprengel Museum Hanover. Recuperado el 15 de mayo 2016 de: https: / / merzbarnlangdale.wordpress.com/

55. El mito del viaje al inframundo. Reproducción graficada de una pictografía azteca. Detalle. De: Danzel, Th. (1922) Mexico I. Bilderhandschriften. Hagen i.W. und Darmstadt, Folkwang-Verlag G.m.b.H..,

56. Anónimo, comienzos del siglo X, Evangeliario de San Medardo - San Juan. Pintura medieval con perspectiva múltiple. Recuperado el 20 de abril 2016 de: https: / / es. wikipedia.org/wiki/ Arte_carolingio

57. Rafael Sanzio, 1509, La Escuela de Atenas. Pintura renacentista: perspectiva central l. Recuperado el 20 de abril 2016 de: http: / / www.nreda2.com/enredados-en-la-cultura/ pintura/146-escuela-de-atenas-rafael-sanzio.html

58. Klee, Borrado de la lista, 1933, colores al óleo sobre papel encerado transparente, 1938. Recuperado el 15 de abril 2016 de: http: / /www.kunstkopie.de/a/paul_klee/ vonderlistegestrichen1933.html

59. Klee, Danzas cansadas por el miedo, 1938, acuarela negra sobre papel ingres sobre cartulina. Recuperado el 15 de abril 2016 de: https://theartstack.com/artist/paul-klee/dancing-underempire-f

60. Klee, Muerte, fuego, 1934, óleo y tempera sobre arpillera. Recuperado el 15 de abril 2016 de: http: / / xsierrav.blogspot.com.co/2015/01/paul-klee-tod-und-feuer.html

61. Klee, Arrebato de miedo II, 1939, acuarela sobre papel ingres sobre cartulina. Recuperado el 15 de abril 2016 de: http:/ /www.swissinfo.ch/direktedemokratie/klee-trifft-picasso-inbern $/ 9021350$

62. Klee, Revolución del viaducto, 1939, óleo sobre lienzo. Recuperado el 15 de abril 2016 de: https: / / es.pinterest.com/pin/448671181601413817/ 